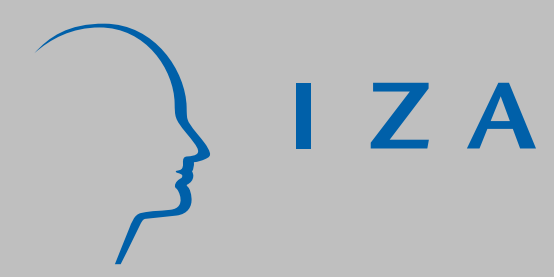

IZA DP No. 749

The Educational Attainment of the Children of the Danish 'Guest Worker' Immigrants

Vibeke J akobsen

Nina Smith

April 2003 


\title{
The Educational Attainment of the Children of the Danish 'Guest Worker' Immigrants
}

\author{
Vibeke Jakobsen \\ AMID, CIM and Danish National Institute of Social Research \\ Nina Smith \\ Aarhus School of Business, CIM, DIW Berlin \\ and IZA Bonn
}

Discussion Paper No. 749
April 2003

IZA

P.O. Box 7240

D-53072 Bonn

Germany

Tel.: +49-228-3894-0

Fax: +49-228-3894-210

Email: iza@iza.org

This Discussion Paper is issued within the framework of IZA's research area Mobility and Flexibility of Labor. Any opinions expressed here are those of the author(s) and not those of the institute. Research disseminated by IZA may include views on policy, but the institute itself takes no institutional policy positions.

The Institute for the Study of Labor (IZA) in Bonn is a local and virtual international research center and a place of communication between science, politics and business. IZA is an independent, nonprofit limited liability company (Gesellschaft mit beschränkter Haftung) supported by the Deutsche Post AG. The center is associated with the University of Bonn and offers a stimulating research environment through its research networks, research support, and visitors and doctoral programs. IZA engages in (i) original and internationally competitive research in all fields of labor economics, (ii) development of policy concepts, and (iii) dissemination of research results and concepts to the interested public. The current research program deals with (1) mobility and flexibility of labor, (2) internationalization of labor markets, (3) welfare state and labor market, (4) labor markets in transition countries, (5) the future of labor, (6) evaluation of labor market policies and projects and (7) general labor economics.

IZA Discussion Papers often represent preliminary work and are circulated to encourage discussion. Citation of such a paper should account for its provisional character. A revised version may be available on the IZA website (www.iza.org) or directly from the author. 
IZA Discussion Paper No. 749

April 2003

\section{ABSTRACT \\ The Educational Attainment of the Children of the Danish 'Guest Worker' Immigrants"}

This paper analyses the educational attainment of young first generation immigrants in Denmark who are children of the 'guest workers' who immigrated from Turkey, Pakistan and Ex-Yugoslavia in the late 1960s and early 1970s. Beside the traditional intergenerational transmission mechanism, we analyse potential immigrant-specific factors as language proficiency, attending mother-tongue courses and expectations concerning out or return migration from Denmark. The results show that intergenerational transmission effects are strong among 'guest worker' immigrants, especially among men. Other important factors are Danish language proficiency, age at first marriage and a number variables reflecting parents' and own attitudes concerning education, marriage and family. However, the 'guest worker' immigrants are not a homogenous group. The analyses reveal large differences between Turkish, Pakistani and Ex-Yugoslavian 'guest workers' with respect to their educational success and the factors behind.

JEL Classification: J61, J24

Keywords: education, 'guest worker' immigrants, intergenerational transmission

Corresponding author:

Nina Smith

Department of Economics

Aarhus School of Business

Prismet

Silkeborgvej 2

8000 Aarhus C

Denmark

Email: nina@asb.dk

\footnotetext{
* The authors thank Helena Skyt Nielsen, participants at the EALE Conference in Paris 2002 and the workshops at Aarhus School of Business and the Danish National Institute of Social Research for many helpful comments. All remaining errors remain the authors' responsibility.
} 


\section{Introduction}

One of the major questions concerning the integration of immigrants in society and in the labour market relates to the educational investments acquired by young first and second generation immigrants. Since a large fraction of first generation immigrants stem from countries with a fairly low overall educational level, the majority of the parent generation in many immigrant groups are unskilled, sometimes even illiterate, especially women.

Educational attainment is a key factor for the integration process of Danish immigrants. The Danish labour market, as many other European labour markets, places a very high and growing weight on qualifying educational qualifications. The size of the Danish public sector which employs more than one third of the Danish labour force enforces this tendency. For instance in the US, many service jobs are jobs in the private sector and undertaken by workers without a qualifying education, but in Denmark they are jobs in the public sector and jobs requiring a qualifying education of several years after compulsory school (typically short theoretic education or vocational training). Therefore, it is of great importance that the young immigrants succeed in getting qualifying educational skills if they shall succeed in getting access to the Danish labour market.

This study focuses on the sons and daughters of the guest workers who came to Denmark from Pakistan, Turkey and Ex-Yugoslavia during the 1960s and early 1970s. The parent generation were primarily unskilled workers who worked in the Danish manufacturing sector. The children of the guest workers may be especially vulnerable because their parents typically have a low educational level, and a large fraction of the parents have experienced very high levels of unemployment and dependency on social income transfers during most of their stay in Denmark.

From many international studies on intergenerational transmission, it is known that the educational background of the parents has a strong influence on that of their offspring. It is also found that the intergenerational mobility is smaller than previously thought, see for instance the survey in Solon (1999). If the assimilation process of immigrants is running fast, the intergenerational transmission might be expected to be less important for young immigrants compared to natives because the children of immigrants will be in a much better position than 
their parents if they grow up in the host country, learn the host country's language in their childhood and attend the host country's school system. But there may be many reasons to expect that immigrants also face opposing forces which may enforce the intergenerational transmission. In a number of papers by Borjas, see for instance Borjas (1992, 1993, 1994, 1995), the effects of ethnic capital and ethnic neighbourhoods are discussed. Children who belong to an ethnic minority or who grow up in areas with a high ethnic concentration may experience positive or negative effects due to these factors which are additional to the pure parental effect. Further, the educational decision of young immigrants may be affected by the fact that many immigrants face or at least expect to face discrimination in the labour market, and thus the expected return to educational investments may be lower than for native Danes. If some of the immigrants expect to return migrate within a fairly short time, this may also be an argument for lower investments in a Danish education. Alternatively, expectations concerning return migration may affect the choice of type of education.

In some immigrant groups, the traditional role of women is very different from that of native Danish women. The labour force participation rate of Danish women, including women with very young children, is close to the male participation rate. These cultural differences may affect the significance of early marriage and number of children on the amount of investments of immigrant women compared to Danish women.

Based on a survey collected among young first generation immigrants in 1999, this paper focuses on explaining the factors determining whether young first generation immigrants complete a qualifying education and the type of qualifying education they attain. We estimate the factors affecting the decision to start and complete a formal or qualifying education and which type of education is chosen. Further, we investigate the reasons for dropping out of the educational system since high drop-out rates seem to be a major reason for young immigrants not to complete an education.

The results show that intergenerational transmission effects are strong among 'guest worker' immigrants, especially among men. Other important factors are Danish language proficiency and age at first marriage. However, the 'guest worker' immigrants are not a homogenous group. The 
analyses reveal large differences between Turkish, Pakistani and Ex-Yugoslavian 'guest workers' with respect to their educational success and the factors behind.

In Section 2, we briefly put up the theoretical framework, and Section 3 summarizes main findings from the empirical literature. The data used are described in Section 4. In Section 5, the Danish school system is shortly sketched and some preliminary descriptive statistics are presented. Section 6 describes the empirical model, Section 7 contains the estimation results, and finally, Section 8 gives the main conclusions.

\section{Theories on educational choice and intergenerational transmissions}

There is a vast literature on intergenerational transmissions and determinants of children's attainment in the labour market, see for instance the survey of economic and sociological literature in Haveman and Wolfe (1995). The educational attainment of young immigrants as well as natives may be seen as a human capital investment decision of the individual him-/herself or a household decision. In the classical model by Becker and Tomes (1979), a simple family utility function (Cobb-Douglas) is specified depending on consumption, $C$, and life time income of the child, $y$. The lifetime income of the parents is allocated on consumption and investments, $I$, in the earnings potential of the children. ${ }^{1}$ Using the notation and the model presented in Solon (1999) and denoting the parent generation by the subscript $t-1$ and the child generation by $t$, we assume that the family (or the parents) maximizes

(1) $U=(1-\alpha) \log C_{t-1}+\alpha \log y_{t} \quad$ s.t. $\quad y_{t-1}=C_{t-1}+I_{t-1}$

$(0<\alpha<1)$. The investments of the parents are assumed to be transformed into an earnings potential of the child given by a simple human capital function

(2) $y_{t}=(1+r) I_{t-1}+E_{t}$

\footnotetext{
${ }^{1}$ In fact, the simple model has a number of limitations. The model implicitly assumes only one child, and it is much more complicated to model a household with more than one child, see for instance Chiswick (1988). We also ignore that both parents or only one of the parents may contribute to the family income, and that assortative mating may affect the intergenerational process. Further, the choice of utility function is somewhat arbitrary.
} 
where $r$ is the return to human capital investments which is assumed to be constant over time, and $E$ is other factors than human capital investments which affect the child's earnings potential, i.e. abilities, genetic heritage etc. Inserting (2) in (1) and maximizing gives the first order condition

$$
I_{t-1}=\alpha y_{t-1}-[(1-\alpha) /(1+r)] E_{t} .
$$

Substituting (3) into (2) gives

(4) $y_{t}=(1+r) \alpha y_{t-1}+\alpha E_{t}$.

Thus, according to (3) the parents' educational investments in the child's earnings capacity depend positively on the lifetime income of the parents and the abilities etc. of the child. The coefficient $\rho=(1+r) \alpha$ in relation (4) represents the intergenerational correlation between the income potential of the parents and the child, and this is the key parameter to be estimated in many papers. In practice, the estimation of $\rho$ is not straightforward because a number of unobserved factors included in $E_{t}$ may be correlated with the values of $E$ for the parent generation, $E_{t-1}$, and this may seriously bias the estimates of $\rho$, see for instance Solon (1999) and Ginther et al. (2000).

When analysing the educational attainment of young immigrants, the traditional intergenerational model may be extended with ethnic-specific factors. According to Borjas $(1992,1994)$, the intergenerational transmission process of immigrants in (2) may include an additional or external effect from the human capital of the parent generation, ethnic capital. Ethnic capital is the average human capital in the ethnic group in which the child is raised. A child growing up in an ethnic group with a high value of ethnic capital will tend to get a high level of human capital himself, given the human capital investments from own parents. The notion of ethnic capital may also include cultural and linguistic skills which are important for the earnings potential in the host country. The concept of ethnic capital is fairly parallel to the concept of 'social capital', see Coleman (1988). 
A third potential effect in the intergenerational transmission process is neighbourhood effects. The concept of neighbourhood effects was introduced into the analyses of second generation immigrants by Borjas $(1992,1995)$. If a child grows up in a community with a high fraction of inhabitants being immigrants, the child is more exposed to meet immigrants and less exposed to meet natives, ceteris paribus. This may have an effect on the skills of the child which is separate from the effects of 'ethnic capital'. Of course there may also exist neighbourhood effects for native children. For instance children who are raised in areas with many poor people or areas with a high rate of crime may have other role models than children who are raised in rich neighbourhoods. Another potential neighbourhood effect is that the school quality may be lower in neighbourhoods with many dual language immigrants children or social clients.

Including these effects in the intergenerational process, we have

(2a) $y_{t}=(1+r) I_{t-1}+\theta K_{t}+\kappa N_{t}+E^{\prime}{ }_{t}$

where $\theta$ and $\kappa$ are parameters and $E_{t}{ }_{t}$ represents other variables affecting the earnings capacity of the child, excluding human capital investments, ethnic capital and neighbourhood effects. Thus we get the following measure of the educational investments in an immigrant family

(3a) $I_{t-1}=\alpha y_{t-1}-[(1-\alpha) /(1+r)]\left(\theta K_{t}+\kappa N_{t}+E^{\prime}{ }_{t}\right)$.

When analysing intergenerational transmissions and educational investments among immigrants, there are other modifications which are not captured by ( $3 a)$. If immigrants face discrimination in the labour market which implies that the return to educational investments is lower than for young natives, this may induce the parents (and the children) to invest less in education than natives. This pre-market discrimination effect is well-known from studies on gender discrimination, see for instance Cain (1986), but the theory of pre-market discrimination may as well be applied when analysing immigrants, see Chiswick (1988). Studies on Danish immigrants indicate that the return to educational investments in the host country is considerably lower for immigrants than for natives, see Husted et al. (2001). Though this effect might stem from demand as well as supply factors or measurement errors in acquired human capital, the 
existence of pre-market discrimination effects cannot be ruled out.

Another modification is the importance of age at immigration. It is a general finding, see for instance Schaafsma and Sweetman (2001), that the age at immigration is extremely important for the educational attainment and earnings. Schaafsma and Sweetman (2001) find that the level of education and earnings decreases with age of immigration for the persons who migrated to Canada before they attained the age of 20 . The same result is found for young immigrants in Denmark, see Hummelgaard et al. (1998). Schaafsma and Sweetman (2001) also observe that immigrants who arrive in the teen years and to a lesser extent those who arrive in their early twenties complete fewer years of education than those who arrive earlier and later. This indicate that migration in the last years of basic school and high school in particular has permanent negative effects on the immigrants' level of education. A smaller analysis by Cahan et al. (2001) indicates that the foreign language acquisition factor plays a central role in the negative relationship between education and age at immigration. Acquisitions of knowledge about the Danish society, including knowledge about the educational system and the labour market, may also have a positive effect on the intergenerational mobility and influence the relationship between education and age at immigration.

A major question in many countries is the importance of offering language courses in mother tongue for immigrant children. Until recently, Danish law commits the municipalities to offer immigrant school children courses in their mother tongue or the official language in their country of origin, and the majority of bilingual first and second generation immigrant children attend these courses. Some researchers argue that mother-tongue courses have positive effects on the general learning of immigrant children, while other researchers stress the negative effects that mother-tongue courses tend to slow down the immigration process, see for instance Lazear (1999) and Duignan (1998). The former view has dominated the Danish debate and Danish policy, see for instance Dennild (2000).

Another additional factor is the possibility of return migration. If an immigrant family expects to return to their origin country, they may not want to invest as much in the host country's educational system as natives or other immigrants who do not expect to return migrate, see 
Dustmann (2001a). Another effect may be that young immigrants choose types of educational investments which are more easy to transfer to their origin country in case of return migration. This may induce immigrant students to prefer for instance medicine and engineering while law studies and educations narrowly directed towards a job in the Danish welfare service system (pedagogical and care worker educations) may be considered less attractive.

Finally, a number of more cultural differences may exist between immigrant groups and compared to natives. Some of these differences may be differences in attitudes concerning the importance of education which is also captured by the notion of ethnic capital. Other cultural factors or social norms concern women's role in the family which may imply different educational investments for girls and boys.

\section{Earlier research on educational attainment of immigrants}

In the survey by Haveman and Wolfe (1995), one of their conclusions is that the intergenerational mobility is smaller than previously assumed, there is much less room for 'luck' and upwards mobility for the children, and the effects from the parental background are stronger than what is often assumed: 'Children who grow up in a poor or low-income family tend to have lower educational and labour market attainments than children from more affluent families, suggesting that parental choices or attributes that result in reduced access by children to economic resources or opportunities increase the chances of low attainment' (cited from Haveman and Wolfe (1995, p. 1870)). According to the survey in Haveman and Wolfe (1995), the main determinant of the educational attainment of children is the educational level of the parents, especially the educational level of the mother seems to be highly correlated with that of her offsprings.

The results surveyed in Haveman and Wolfe (1995) are all based on US data, and they do not focus on intergenerational mobility among immigrants. In a study by Chiswick (1988) on ethnic minorities in the US, it is found that the major reason for variation in educational investments among ethnic groups is a variation in the household decisions concerning fertility and the investments in 'child quality' which is assumed to depend on the labour supply of the mothers. When controlling for these factors, Chiswick (1988) finds no evidence that differences in educational investments of young Americans and investments of ethnic minorities are due to 
differences in 'tastes' for education, discrimination or differences in time preferences between ethnic groups. Later studies by Borjas $(1992,1993,1995)$ place more weight on the 'ethnic' factor. Borjas finds in a number of studies for the US, that the concept of ethnic capital is an important explanation for the intergenerational mobility of immigrant children. The isolated effect from parental capital (parents' own education) may be slightly less for immigrants than for natives, but when the effects from ethnic capital are added, the picture changes, and the immigrant children experience less mobility than native born children with respect to education and income. The same results are found in Card et al. (1998).

Since income mobility is usually assumed to be smaller in Europe, see for instance Björklund and Jäntti (1997), the results from these US studies may be different from those based on data from European countries. There are few European studies on intergenerational mobility among immigrants, and they typically include young first generation immigrants as well as second generation immigrants. In general, the tendency is that young first generation immigrants have a much lower educational level that second generation immigrants who by definition are born in the host country, and second generation immigrants have a slightly lower educational level than natives.

For Germany, Gang and Zimmermann (2000) find somewhat surprisingly that the parents' education has no effect on the educational attainment of young German first or second generation immigrants while parental capital has significantly positive effects on the length of education for native German youth. Further, for Germany the fairly depressing result is found that the gap between the educational attainment of the native youth and second generation young immigrants has been increasing, see Riphahn (2001). One explanation may be that in the educational system in Germany children choose their educational track already at the age of ten, see Dustmann (2001b). This may have serious consequences for the educational attainment of more vulnarable groups like immigrant children. For the Netherlands, Van Ours and Veenman (2001) find a significantly positive effect of parental capital on the educational attainment of young first and second generation immigrants. Controlling for parental capital, the educational level of young immigrants is not different from that of the native youth in the Netherlands. About the same result is found for Sweden, see Österberg (2000). The lower educational level of most immigrant 
children compared to native children is mainly due to unfavourable background characteristics and parental capital for the immigrant group.

Danish studies on intergenerational mobility are also sparse. Based on Danish register data on the total population of Danish second generation immigrants, Nielsen et al. (2001) and Rosholm et al. (2002) find that second generation immigrants have a considerably lower propensity to complete a qualifying education than native young Danes, but a higher frequency than young first generation immigrants. ${ }^{2}$ Especially immigrants from Turkey and especially men seem to lack behind native Danes. The parental capital is important for second generation immigrants, ethnic capital (average educational level of ethnic group) reinforces this effect and thus reduces the intergenerational mobility of second generation immigrants. Looking instead at the sum of enrolment rates plus completion rates, the difference between native born youth and second generation immigrants is much smaller. This observation reflects that the drop-out rates are larger for immigrants than for native Danes, see the Ministry of Education (2001).

\section{Data}

The empirical analysis is based on a survey of first generation immigrants from the three countries which during the 1960s and early 1970s were the main 'guest worker' countries of Danish immigrants. The data consist of two waves, the first survey was conducted in 1988 among young first generation immigrants aged 18-25 who had lived in Denmark for more than 10 years. 11 years later, in 1999, the same immigrants who were now 28-36 years old, were contacted and interviewed. The sample consists of 827 observations in 1988 and 693 observations in 1999. 529 of the observations were observed in both years. Of the 693 observations in 1999, 213 are from Ex-Yugoslavia, 259 are from Turkey and 221 are from Pakistan, see Just Jeppesen (1989) and Schmidt and Jakobsen (2000) for a more detailed description of the samples.

For comparisons with the Danish population, we also use a data set originating from administrative registers in Statistics Denmark, including information on $10 \%$ of the ethnic Danish population, who were between 28 and 36 years old in 1999 . We will not make use of the

\footnotetext{
2 The same pattern is found for Sweden in Ekberg (1997).
} 
data on ethnic Danes in the statistical/econometric analysis, because the administrative data lack part of the information included in the survey (for instance language proficiency, plans of return migration and all variables describing attitudes and norms).

The dependent variables in this study are: (1) whether the individual is enrolled at or has completed a qualifying education, (2) which type of qualifying education the individual is enrolled at or has completed and (3) the risk of dropping out from a qualifying education conditional on having started. The educational level refers to the year 1999 when the immigrants were aged 28-36 years. We do not use the 1988 information on educational level since very few of the immigrants in the sample had completed a qualifying education in $1988 .^{3}$

The explanatory variables in the study include variables, which are intended to catch some of the intergenerational transformation described in Section 2, demographic variables and variables concerning language proficiency, experienced discrimination, plans to return migrate and participation in mother-tongue courses in childhood and variables included to capture norms and attitudes relevant for the educational decision. Sample means for the sample year 1999 are given in Appendix, Table A.

The demographic variables included in the models are age in 1999 (coded as three indicator variables 28-30, 31-33 and 34-36 years), age at immigration (coded as an indicator variable which assumes the value of 1 if age is 0-6 years), a variable describing whether the immigrants in 1999 have applied for or acquired Danish Citizenship and age at first marriage. The educational level of each of the parents is measured by number of years of schooling and education. The immigrants' language proficiency is measured by the interviewers evaluation in 1999 of the immigrants' Danish language proficiency. If language proficiency is coded as perfect, the language indicator assumes the value of one, and zero else. The neighbourhood effect is measured by a variable based on a question in the 1988 survey on the number of immigrants in the school class at basic school. If the answer was more than 5 immigrants, the indicator variable

\footnotetext{
${ }^{3} \mathrm{We}$ are not able to exploit the panel structure of the data directly by estimating for instance a fixed effects model because the number of individuals who are observed in both years is too low.
} 
assumes the value of one, and else zero. ${ }^{4}$ Ethnic capital is captured by including country-specific indicators. These indicators may of course catch other country differences than ethnic capital. In some of the estimations, we experiment with other attitude variables and variables reflecting social norms which may be related to ethnic capital.

The significance of plans of return migration is examined by a variable describing whether the young immigrants in 1999 definitely or maybe wanted to return migrate. Another variable concerns whether the immigrants have participated in mother-tongue courses in their childhood. The survey contains (subjective) information on whether the person has felt discriminated against in the past. This variable is an index variable based on the information from 3 separate questions: Were you teased in school? Did a teacher treat you worse than the ethnic Danish children? Did you feel uncomfortable in school? They available answers were: 3 = frequently, $2=$ now and then or $1=$ seldom/never. The index is calculated as the mean of the answers in the three questions.

In order to catch cultural differences which may explain for instance gender differences in educational investments, we include an indicator for religion (muslim=1 and others $=0$ ), an indicator if married to a marriage migrant, i.e. a spouse who immigrated to Denmark when the interview person were married, and an indicator variable which assumes the value of one if the interview person says that their children should not be allowed to marry a Dane. These variables are selected because they turned out to be correlated with the variable age at first marriage, which is instrumented because of endogeneity, see the section below. Further tests on the validity of the instruments showed that these attitude variables also directly affect the educational decision, and thus these variables should be included in the educational relation. Additional variables are included in the relation determining age at first marriage. These variables are mainly indicator variables from the 1988 wave: Parent come from rural area, religion is important, parents attitude: children should marry early and their attitude concerning children's return migration, feel more Danish than Turkish/Pakistani/Yugoslavian, many friends who are non-immigrants, married to a person from own family, arranged marriage, and attitudes concerning their own children: they should be allowed to choose their own spouse. Further, a variable measuring ethnic

\footnotetext{
${ }^{4}$ When using 1988 information in the estimations, we code missing information as a zero and add an additional indicator variable which assumes the value of 1 , if information is missing on the variables concerned, zero else.
} 
concentration in the region is used when instrumenting age at first marriage.

\section{The Danish educational system and descriptive statistics on educational attainment of young immigrants}

Compulsory school in Denmark starts at the age of 6 or 7 and includes 9 years of compulsory school (Folkeskolen). After these 9 years, the pupils have the options of 1 extra year at school ('grade 10' in Folkeskolen), to start at high school (gymnasium, general upper secondary), enrolment at a vocational education (apprenticeship, vocational upper secondary) or to leave the qualifying educational system without any education at the age of about 16 years. Figure 1 illustrates the main features of the Danish educational system. A qualifying education (erhvervskompetencegivende uddannelse) is defined as either a completed vocational education (about 4 years) or a completed 'theoretic education' which may be either 'short' (2-4 years, e.g. laboratory technician, dental hygienist and other mainly technical educations), 'medium' (3-4 years, e.g. teacher, nurse, engineer, bachelor) or 'long' (5-6 years, university). Most of the nonvocational educations demand completed high school qualifications, see Figure 1. Thus, if the student completes a theoretic education without any delays or periods out of the educational system, they typically get a university degree at the age of 26 , and for shorter theoretic educations 2-3 years earlier.

Figure 1. Main features of the Danish school and educational system.

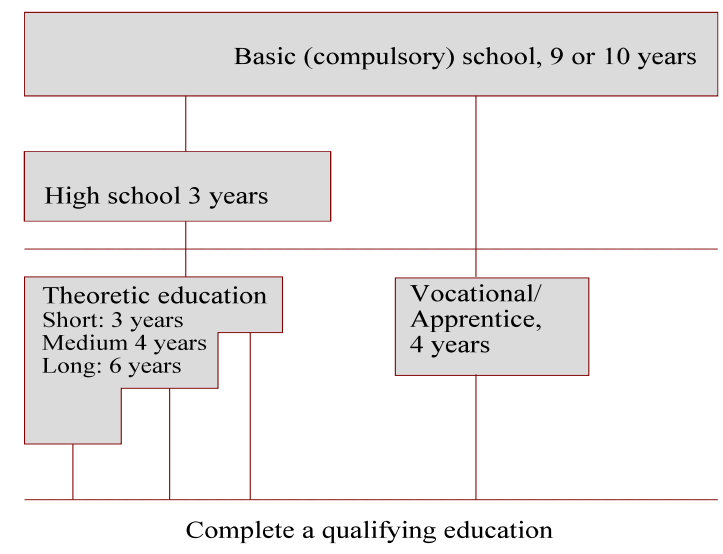
Note: Not all theoretic educations demand a completed high school exam. The length of theoretic educations and
vocational training varies, the figures shown are approximate.

While almost all Danish pupils complete the basic school, this is not the case for young 
immigrants, since a number of these immigrants arrive in Denmark at a fairly high age. Compared to the native Danes, the young immigrants attain a considerably lower level of education. Table 1 shows the educational attainment in 1999 of the individuals included in the sample and, for comparisons, the same figures for native young Danes in the same age categories. Since some of the individuals included in the sample may still be in the educational system, we have also included individuals who are still enrolled but have not completed their education. Especially the proportion of young immigrants who attain a vocational education is low compared to the native Danes. Exactly the same pattern is found for Danish second generation immigrants from Turkey and Pakistan, see Rosholm et al. (2002). On the other hand, the differences are much smaller with respect to acquiring a completed qualifying education from a Danish university.

The young Turkish immigrants and especially the men seem to face large problems with respect to completing a qualifying education. One reason is that a fairly large proportion of the group do not finish basic school with a diploma, probably because they immigrate to Denmark at a fairly high age. Thus, they are not able to get a diploma even from basic school in Denmark, and on the other hand they do not have a basic school diploma from their origin country. A diploma is a condition for being enrolled at an education. Another noteworthy evidence in Table 1 is that Pakistani young immigrants (especially men) have a high proportion who are enrolled or have completed a theoretic education, especially at the university level. This proportion is as high as for native young Danes. Young immigrants from Ex-Yugoslavia seem to prefer the vocational training system to theoretic education. This is contrary to young immigrants from Pakistan and Turkey who have much lower tendency to be enrolled or complete a vocational education.

Thus, there are very clear differences between the educational patterns of the three groups included in this study. The latter part of Table 1 shows (i) the proportion of immigrants who have completed a qualifying education and (ii) the proportion of immigrants who have either finished or is enrolled at a qualifying education. Despite the fairly high age of the individuals in the sample (28 - 36 years), about 10\% are still enrolled in the educational system, which is a higher fraction than for ethnic Danes of the same age. This is closely related to the fact that the immigrants on average are older than ethnic Danes when they obtain a diploma from basic school. A major explanation of this delay in completing an education is language problems, see 
Cahan et al. (2001).

Table 1. Educational attainment (highest level of completed education or ongoing education) of young first generation immigrants and ethnic Danes. Age group 28-36. 1999.

\begin{tabular}{|c|c|c|c|c|c|c|c|c|}
\hline & \multicolumn{2}{|c|}{ Turkey } & \multicolumn{2}{|c|}{ Pakistan } & \multicolumn{2}{|c|}{ Ex-Yugoslavia } & \multicolumn{2}{|c|}{ Denmark } \\
\hline & Men & Women & Men & Women & Men & Women & Men & Women \\
\hline No education (no school diploma) & 27.8 & 40.6 & 5.2 & 6.9 & 6.8 & 20.9 & 0.0 & 0.0 \\
\hline Only basic school & 41.3 & 22.6 & 25.2 & 22.1 & 21.4 & 22.7 & 23.7 & 21.0 \\
\hline High school & 4.0 & 0.8 & 8.1 & 7.0 & 3.9 & 2.7 & 5.2 & 6.9 \\
\hline Vocational & 11.9 & 18.8 & 13.3 & 27.9 & 37.9 & 27.3 & 45.1 & 39.3 \\
\hline Short theoretic & 4.0 & 9.0 & 14.8 & 16.3 & 12.6 & 9.1 & 6.3 & 5.0 \\
\hline Medium theoretic & 7.1 & 6.8 & 13.3 & 7.0 & 13.6 & 11.8 & 9.6 & 17.5 \\
\hline Long theoretic & 4.0 & 1.5 & 20 & 12.8 & 3.9 & 5.5 & 10.2 & 10.3 \\
\hline Total & 100.0 & 100.0 & 100.0 & 100.0 & 100.0 & 100.0 & 100.0 & 100.0 \\
\hline $\begin{array}{l}\text { Completed or enrolled at a } \\
\text { qualifying education, proportion of } \\
\text { group }{ }^{1)}\end{array}$ & 27.0 & 36.1 & 61.4 & 64.0 & 68.0 & 53.7 & 71.2 & 72.1 \\
\hline $\begin{array}{l}\text { Completed a qualifying educa-tion, } \\
\text { proportion of group }{ }^{1)}\end{array}$ & 26.2 & 26.3 & 52.6 & 55.8 & 60.2 & 45.5 & 68.2 & 68.0 \\
\hline $\mathrm{N}$ & 126 & 133 & 135 & 86 & 103 & 110 & 33,852 & 32,542 \\
\hline
\end{tabular}

1) Qualifying education is defined as vocational, short theoretic, medium theoretic or long theoretic education, see Figure 1 .

One obvious explanation for the results in Table 1 may be the educational level of the parents. In Table 2, the educational attainment of the parents is compared to that of the children. Table 2 shows the average length of education, including years of schooling, for the fathers and mothers of the young immigrants included in the sample, distributed by educational attainment of the latter (child) generation. There are considerable differences between the parent generations from the three countries with respect to educational attainment. Pakistani parents (fathers) are far more educated than Turkish parents and also have a longer education than the average Danish fathers in this study. Especially the mothers from Turkey have a very low level of schooling and education, on average 1-2 years..$^{5}$ Thus, it is clearly a large challenge for a young Turkish immigrant to complete a qualifying education which including the schooling years may take 13-

\footnotetext{
${ }^{5}$ The educational level of the parents of the young immigrants analysed in this study is considerably lower than the educational level of the total group of adult first generation immigrants (the level of ethnic capital) from the countries concerned. Thus, the group of 'guest workers' and their spouses who arrived in the late $1960 \mathrm{~s}$ and early 1970 s are not representative for the total immigrant population with respect to educational level.
} 
19 years. For Turkish and partly Pakistani immigrants, there is no clear pattern in Table 2 that the longer the education of the parents, the longer the education of the children. This is opposite to the pattern for Ex-Yugoslavian and Danish children, where there is a clear positive relationship in Table 2 between parents' and children's educational level.

Table 2. Educational attainment (highest level of completed education or ongoing education) of young first generation immigrants and ethnic Danes (age group 28-36) compared to their fathers' and mothers' schooling and educational level. 1999.

\begin{tabular}{lcccccccccccc}
\hline & \multicolumn{3}{c}{ Turkey } & \multicolumn{3}{c}{ Pakistan } & \multicolumn{3}{c}{ Ex-Yugoslavia } & \multicolumn{2}{c}{ Denmark } \\
& father & mother & child & father & mother & child & father & mother & child & father & mother & child \\
\hline Child education: & \multicolumn{2}{c}{ years } & $\%$ & years & $\%$ & years & $\%$ & years & $\%$ \\
$\begin{array}{l}\text { No education (no } \\
\text { school diploma) }\end{array}$ & 3.0 & 1.2 & 34.4 & 8.5 & 3.4 & 5.9 & 4.0 & 3.0 & 14.1 & - & - & 0.0 \\
Only basic school & 3.2 & 1.3 & 31.2 & 8.6 & 3.9 & 24.0 & 6.5 & 5.5 & 22.1 & 7.0 & 6.6 & 22.3 \\
High school & 2.9 & 1.4 & 2.3 & 11.8 & 5.9 & 7.7 & 8.1 & 6.7 & 3.3 & 9.8 & 9.3 & 6.1 \\
Vocational & 4.3 & 2.2 & 15.4 & 9.3 & 4.5 & 19 & 7.6 & 6.7 & 32.4 & 8.4 & 7.9 & 42.3 \\
Short theoretic & 3.0 & 1.5 & 6.6 & 10.3 & 5.5 & 15.4 & 9.2 & 7.5 & 10.8 & 9.7 & 9.2 & 5.7 \\
Medium theoretic & 2.8 & 1.4 & 7.0 & 9.4 & 5.1 & 10.9 & 9.4 & 8.2 & 12.7 & 9.9 & 9.6 & 13.5 \\
Long theoretic & 3.3 & 2.1 & 2.7 & 11.8 & 6.6 & 17.2 & 10.3 & 8.4 & 4.7 & 11.2 & 10.9 & 10.2 \\
\hline Total & 3.2 & 1.4 & 100.0 & 9.9 & 5.0 & 100.0 & 7.4 & 6.3 & 100.0 & 8.7 & 8.3 & 100.0 \\
N & 243 & 250 & 259 & 210 & 208 & 221 & 185 & 192 & 213 & 60,729 & 64,915 & 66,394 \\
\hline
\end{tabular}

One explanation behind the different educational attainment among young immigrants from the three countries may be differences in enrollment rates to and drop-out rates from the educational system. Table 3 shows gender- and country-specific rates. A much larger proportion of Turkish immigrants, about half of the group, have never been enrolled at an education compared to Pakistani and Ex-Yugoslavian immigrants. For Pakistani immigrants this is only about $20 \%$ and for Ex-Yugoslavian immigrants 14\% for men and 37\% for women. Further, conditional on having ever been enrolled, the drop-out rate is much higher for Turkish students, again about half of the male Turkish students drop-out, while Turkish female students have more success if they enroll at an education. Only about $24 \%$ of the Turkish female students drop-out, while this figure is slightly lower for Pakistani and Ex-Yugoslavian young immigrants.

Far the largest drop-out rates are observed for vocational training. This type of training usually 
demands that part of the education takes place at a local firm (practical education) and in Denmark there has been a lack of firms who are willing to support these 'places' for students. If there is discrimination in the selection of students who get a place at a firm, this may partly explain the high drop-out rates and the low proportion of young immigrants from Turkey and Pakistan who are enrolled or complete a vocational education, see The Board for Ethnic Equality (1996).

Table 3. Drop-outs from the educational system. Age group 28-36.1999.

\begin{tabular}{|c|c|c|c|c|c|c|}
\hline & \multicolumn{2}{|c|}{ Turkey } & \multicolumn{2}{|c|}{ Pakistan } & \multicolumn{2}{|c|}{ Ex-Yugoslavia } \\
\hline & Men & Women & Men & Women & Men & Women \\
\hline \multicolumn{7}{|l|}{ Q1. Dropped out from an education } \\
\hline No, never enrolled & 48.4 & 52.6 & 19.3 & 18.6 & 13.6 & 37.2 \\
\hline No, enrolled or completed & 27.0 & 36.1 & 61.4 & 64.0 & 68.0 & 53.7 \\
\hline $\begin{array}{l}\text { Yes, and not completed or enrolled } \\
\text { at another education in } 1999\end{array}$ & 24.6 & 11.3 & 19.3 & 17.4 & 18.4 & 9.1 \\
\hline $\operatorname{Total}(\mathrm{N})$ & $100(126)$ & $100(133)$ & $100(135)$ & $100(86)$ & $100(103)$ & $100(110)$ \\
\hline Drop-out rate ${ }^{1)}$ & 0.477 & 0.238 & 0.239 & 0.214 & 0.213 & 0.145 \\
\hline \multicolumn{7}{|l|}{$\begin{array}{l}\text { Q2. If yes in Q1, dropped out from } \\
\text { which education? }\end{array}$} \\
\hline Vocational & 90.3 & 73.3 & 65.4 & 80.0 & 89.5 & 80.0 \\
\hline Other & 9.7 & 26.7 & 34.6 & 20.0 & 10.5 & 20.0 \\
\hline $\operatorname{Total}(\mathrm{N})$ & $100(31)$ & $100(15)$ & $100(26)$ & $100(15)$ & $100(19)$ & $100(10)$ \\
\hline
\end{tabular}

Note: The survey contains no information on change of education, i.e. there is no information on whether the interview person has ever dropped out from an education, whether he or she has currently completed an education or is enrolled.

1) Drop-out rate is defined as Row 3 divided by the sum of Row 2 and Row 3.

\section{Empirical specification}

There are many dimensions of educational attainment of young people. In this study, we focus on the success with respect to acquiring a qualifying education, i.e. we do not consider a completed basic school or high school. We analyse the factors behind the following measures of 'educational success':

i) EDUCI: A dichotomous variable which assumes the value 1 if the person has a completed qualifying education, 0 else.

ii) EDUCII: A dichotomous variable which assumes the value 1 if the person has completed or is enrolled at a qualifying education.

iii) LEVELI: An ordered discrete variable which assumes the values 0, 1, 2, 3 and 4 
representing the levels of completed qualifying education (No qualifying education, vocational, short, medium, long), see below.

iv) LEVELII: An ordered discrete variable which assumes the values 0, 1, 2, 3 and 4 representing the levels of completed or ongoing qualifying education (No qualifying education, vocational, short, medium, long), see below.

v) Drop-out: A dichotomous variable which assumes the value 1 if dropped out from a qualifying education and not started on another education (conditional of having started), 0 if not dropped out or started on another education, but has been enrolled at least once. Those who have never been enrolled at any education are not included.

Assume that the educational investments of individual $i$ may be represented by an unobserved latent variable $y_{i}^{*}$

$$
y_{i}^{*}=X_{i} \beta+\epsilon_{i}
$$

$\beta$ is a column vector of parameters to be estimated, $\boldsymbol{X}_{\boldsymbol{i}}$ is a row vector of explanatory variables and $\epsilon_{i}$ is an independent and normally distributed error term.

In the models where we observe a dichotomous endogenous educational variable, i.e. the models for EDUCI and EDUCII, we apply a probit specification: ${ }^{6}$

$$
\operatorname{Pr}\left(Y_{i}=1\right)=\operatorname{Pr}\left(y_{i}^{*}>0\right)=\operatorname{Pr}\left(\epsilon_{i}<\boldsymbol{X}_{i} \beta\right)=\Phi\left(\boldsymbol{X}_{i} \beta\right)
$$

where $\Phi$ is the cumulative standard normal distribution.

The models for level of education (LEVELI, LEVELII) are estimated by an ordered probit specification which allows us to use the educational information more intensively than the dichotomous probit specification. Assume that the educational level is represented by $J$ categories, and assume that $Y=0$ if $y^{*}<\mu_{1}, Y=1$ if $\mu_{1} \leq y^{*}<\mu_{2}, \ldots, Y=J$ if $y^{*} \geq \mu_{J}$, where $\mu_{l}, \ldots$, $\mu_{J}$ are unknown cut-off points to be estimated:

$$
\operatorname{Pr}\left(Y_{i}=j\right)=\operatorname{Pr}\left(\mu_{j-1}<X_{i} \beta<=\mu_{j}\right)=\Phi\left(\mu_{j}-X_{i} \beta\right)-\Phi\left(\mu_{j-1}-X_{i} \beta\right)
$$

\footnotetext{
${ }^{6}$ The probit specification is also used for the drop-out variable but in this case the interpretation of the unobserved latent variable is of course different from the other models.
} 
where the index $j=0,1, \ldots, J$ indicates education level, $\mu_{l}, \mu_{2}, \ldots \mu_{J}$ are cut-off points, which separate the adjacent categories $\left(0<\mu_{1}<\mu_{2}<\ldots \ldots<\mu_{J}\right)$.

It may be criticized that this ordering of the educations from 0 to $J$ (where $J$ is equal to 4 in our model) is not reflecting the educational 'level' adequately, especially in the case of vocational training and a short theoretic education. Often a person with a vocational education has also attended high school, see Figure 1, and therefore this education may not be ranging lower than 'short theoretic'. In alternative estimations not shown, we have pooled these two categories into one, and this does not have any notable effect on the obtained estimates.

A general problem in most of the estimated models in this study is that some of the explanatory variables may suffer from endogeneity. Especially, the variable age at first marriage is suspected to be endogenous, since marriage may be considered to be an alternative if failure in the educational system. Further, there may be a number of unobserved variables relating to e.g. attitudes or culture, which affect both the probability of early marriage and the probability of completing a qualifying education. In order to account for this problem, we experiment with instrumenting the marriage variable. The critical problem is to find valid instruments. The instruments chosen are partly based on information from the 1988 survey in order to reduce as much as possible a potential correlation between the instruments and error terms in the relation explaining education. In Section 7 and Appendix C, choice and test of instruments are described in further details.

Another problem relating to the instrumentation of age at first marriage is that this variable is right censored - we only know the age at first marriage for those immigrants who were married before the interview in 1999. Therefore, we use a generalization of the tobit model, which allows the censoring values to vary individually across observations. Assume that $Z$ is the observed age at first marriage, and $z *$ is an unobserved latent variable, $z^{*}=X_{z} \gamma+v$ defined parallel to $y^{*}$ in (5). We estimate the model

$$
Z_{i}=z_{i}^{*} \text { if } z_{i}^{*} \leq a_{i} \text { and } Z_{i}=a_{i} \text { if } z_{i}^{*}>a_{i}
$$


where $a_{i}$ is individual $i$ 's age, observed in 1999. Thus, the threshold for the latent variable varies between individuals. Based on this estimation, we calculate a predicted value of the variable age at first marriage and include this predicted variable in some of the estimations. ${ }^{7}$ The tobit estimations of age at first marriage are shown in Appendix C.

\section{Results}

\subsection{The probability of getting a qualifying education}

In Tables 4 and 5, we present the results (coefficients and marginal effects) from probit estimations of the probability of having completed or still being enrolled at a qualifying education. We have estimated alternative models with the endogenous variable being either 'completed education' (EDUCI and LEVELI) or 'completed or ongoing education' (EDUCII and LEVELII). The results were fairly similar, and thus we present only the latter results. The results from estimating an ordered probit model are shown in the Appendix B. The structure of the coefficients from these estimations is pretty close to that of the simple probit, but since the calculated marginal effects (evaluated at sample means) differ between educational levels, the marginal effects include further information on educational behaviour. The marginal effects for the alternative educational levels based on the ordered probit specification are also presented in Appendix B.

The number of observations in the estimations and the degrees of freedom are not very high, and therefore we have to limit the number of included explanatory variables in each regression. The estimations presented are selected among a number of experimental estimations where different variables have been included and excluded in different specifications because a number of explanatory variables turned out to be highly correlated. As an example, the educational level of the father and the mother is strongly positively correlated and when both variables are included, one of them or both often become insignificant. The education of the mother seems to be the most important explanatory variable (this results is in agreement with other international studies, see Section 3), and this variable is selected in the estimations. Another example is a strong

\footnotetext{
${ }^{7}$ All models are estimated by STATA. Since we include the instrumented variable for age at first marriage in most of the estimations, the standard errors of the coefficients in these estimations should take into account the instrumentation. The standard errors of the coefficients presented are not corrected for this bias, i.e. significance may be overstated.
} 
negative correlation between the variables 'age at marriage' and 'number of children'. Again, age at marriage is selected in the estimations because this variable seems to be the most important.

The first four columns of Table 4 show the estimation results when no explanatory variables are instrumented, while the last four columns show the same models, but with age at first marriage instrumented. The test of instruments, see Appendix C, indicates that it is not a straightforward task to select variables which only affect the age at first marriage and not the educational level. For instance the attitude variables reflecting religion, whether married to a marriage migrant, and the attitudes towards marriage behaviour of the children which a priori were included only in the age at first marriage relation also seem to have an independent effect on education according to Appendix C. Thus, in general, the identification seems weak. With these reservations in mind, we prefer to discuss the results from the estimations without using IV but including the attitude variables which the IV-test revealed to affect the educational attainment.

Despite the considerable differences between young immigrants from Turkey, Pakistan and ExYugoslavia and between men and women, described in the simple cross tabulations in Section 5 , the gender and country indicators do not turn out to be significant in Table 4 when a number of other variables are accounted for. The only exception is in column 4, where women from Pakistan have a significantly higher propensity to complete an education. The age indicators are not significant either, i.e. most young immigrants tend to have completed their education at the age of 28 , and relatively few immigrants complete their education after that age.

Parental capital is important. The education of the mother has a significantly positive effect on the probability of obtaining a qualifying education. The size of the marginal effect on the chances of completing or being enrolled at a qualifying education is about $2 \%$ (Table 5), highest for men while smaller but almost significant for women. The figure of $2 \%$ implies that having a mother with only about 1.5 years of schooling (like Turkish mothers) compared to about 6.5 years (like Ex-Yugoslavian mothers) reduces the probability of completing or being enrolled at a qualifying education with about 10 percentage points, i.e. 10 percentage points of the educational gap between Turkish and Ex-Yugoslavian young immigrants may be explained by differences in the educational level of the mother. According to Table B.2, the mother's education in particular has a positive effect on the chances of completing or being enrolled at a medium or long theoretic 
education, while the mother's education in the case of female immigrants has a more positive effect on the chances of completing or being enrolled at a vocational, short or medium theoretic education than at a long theoretic education.

Table 4. Coefficients from estimation of the probability of being enrolled or having completed a qualifying education - basic model. 1999. Probit specification. (Std. err. in parentheses)

\begin{tabular}{|c|c|c|c|c|c|c|c|c|}
\hline & All & All & Men & Women & $\begin{array}{c}\text { All } \\
\text { IV }^{1)}\end{array}$ & $\begin{array}{c}\text { All } \\
\text { IV }^{1)}\end{array}$ & $\begin{array}{l}\text { Men } \\
\mathrm{IV}^{11}\end{array}$ & $\begin{array}{l}\text { Women } \\
\text { IV }^{1)}\end{array}$ \\
\hline Age indicators & insignificant & insignificant & insignificant & insignificant & insignificant & insignificant & insignificant & insignificant \\
\hline Gender indicator & insignificant & insignificant & - & - & insignificant & insignificant & - & - \\
\hline Pakistani & $\begin{array}{c}0.124 \\
(0.147)\end{array}$ & $\begin{array}{l}0.398^{* *} \\
(0.184)\end{array}$ & $\begin{array}{c}0.286 \\
(0.247)\end{array}$ & $\begin{array}{c}0.780 * * \\
(0.317)\end{array}$ & $\begin{array}{l}0.140 \\
(0.145)\end{array}$ & $\begin{array}{l}0.470 * * \\
(0.197)\end{array}$ & $\begin{array}{c}0.387 \\
(0.269)\end{array}$ & $\begin{array}{c}0.778^{* *} \\
(0.331)\end{array}$ \\
\hline Turkish & $\begin{array}{l}-0.158 \\
(0.161)\end{array}$ & $\begin{array}{c}0.071 \\
(0.071)\end{array}$ & $\begin{array}{l}-0.091 \\
(0.263)\end{array}$ & $\begin{array}{c}0.381 \\
(0.302)\end{array}$ & $\begin{array}{l}-0.197 \\
(0.161)\end{array}$ & $\begin{array}{l}0.058 \\
(0.193)\end{array}$ & $\begin{array}{l}-0.178 \\
(0.270)\end{array}$ & $\begin{array}{c}0.365 \\
(0.306)\end{array}$ \\
\hline Mother's education & $\begin{array}{c}0.057 * * * \\
(0.017)\end{array}$ & $\begin{array}{c}0.050 * * * \\
(0.017)\end{array}$ & $\begin{array}{l}0.062 * * \\
(0.024)\end{array}$ & $\begin{array}{l}0.042 * \\
(0.025)\end{array}$ & $\begin{array}{c}0.049 * * * \\
(0.017)\end{array}$ & $\begin{array}{c}0.055^{* * *} \\
(0.017)\end{array}$ & $\begin{array}{c}0.073 * * * \\
(0.025)\end{array}$ & $\begin{array}{c}0.041 \\
(0.026)\end{array}$ \\
\hline $\begin{array}{l}\text { Age at immigration 0-6 } \\
\text { year }\end{array}$ & $\begin{array}{c}0.032 \\
(0.145)\end{array}$ & $\begin{array}{c}0.130 \\
(0.148)\end{array}$ & $\begin{array}{c}0.0394 * \\
(0.217)\end{array}$ & $\begin{array}{l}-0.348 \\
(0.220)\end{array}$ & $\begin{array}{l}-0.019 \\
(0.145)\end{array}$ & $\begin{array}{l}0.005 \\
(0.147)\end{array}$ & $\begin{array}{c}0.294 \\
(0.211)\end{array}$ & $\begin{array}{l}-0.336 \\
(0.222)\end{array}$ \\
\hline Age at first marriage & $\begin{array}{c}0.069 * * * \\
(0.020)\end{array}$ & $\begin{array}{c}0.056 * * * \\
(0.021)\end{array}$ & $\begin{array}{c}0.093 * * * \\
(0.029)\end{array}$ & $\begin{array}{c}0.024 \\
(0.034)\end{array}$ & $\begin{array}{l}0.060^{*} \\
(0.018)\end{array}$ & $\begin{array}{l}-0.022 \\
(0.036)\end{array}$ & $\begin{array}{l}-0.040 \\
(0.052)\end{array}$ & $\begin{array}{c}0.007 \\
(0.054)\end{array}$ \\
\hline Language: Very good & $\begin{array}{c}0.882 * * * \\
(0.136)\end{array}$ & $\begin{array}{c}0.859^{* * *} \\
(0.138)\end{array}$ & $\begin{array}{c}0.574 * * * \\
(0.194)\end{array}$ & $\begin{array}{c}1.118^{* * *} \\
(0.208)\end{array}$ & $\begin{array}{c}0.859^{* * *} \\
(0.139)\end{array}$ & $\begin{array}{c}0.941 * * * \\
(0.144)\end{array}$ & $\begin{array}{c}0.712 * * * \\
(0.206)\end{array}$ & $\begin{array}{c}1.159^{* * *} \\
(0.216)\end{array}$ \\
\hline $\begin{array}{l}\text { Neighbourhood: More than } \\
5 \text { immigrants in school } \\
\text { class }\end{array}$ & $\begin{array}{l}-0.058 \\
(0.129)\end{array}$ & $\begin{array}{l}-0.487 \\
(0.321)\end{array}$ & $\begin{array}{l}-0.148 \\
(0.437)\end{array}$ & $\begin{array}{c}-1.034 * * \\
(0.532)\end{array}$ & $\begin{array}{l}-0.469 \\
(0.320)\end{array}$ & $\begin{array}{l}-0.475 \\
(0.319)\end{array}$ & $\begin{array}{l}-0.655 \\
(0.714)\end{array}$ & $\begin{array}{c}-1.051 * * \\
(0.535)\end{array}$ \\
\hline $\begin{array}{l}\text { Married to a marriage } \\
\text { migrant }\end{array}$ & - & $\begin{array}{l}-0.213 \\
(0.149)\end{array}$ & $\begin{array}{l}-0.032 \\
(0.212)\end{array}$ & $\begin{array}{c}-0.426^{* *} \\
(0.217)\end{array}$ & - & $\begin{array}{c}-0.471^{* *} \\
(0.218)\end{array}$ & $\begin{array}{l}-0.521 * \\
(0.322)\end{array}$ & $\begin{array}{l}-0.494 \\
(0.327)\end{array}$ \\
\hline Religion: Islam & - & $\begin{array}{c}-0.367^{* *} \\
(0.174)\end{array}$ & $\begin{array}{l}-0.322 \\
(0.242)\end{array}$ & $\begin{array}{l}-0.492 * \\
(0.283)\end{array}$ & - & $\begin{array}{c}-0.469 * * \\
(0.203)\end{array}$ & $\begin{array}{l}-0.421 \\
(0.281)\end{array}$ & $\begin{array}{l}-0.487 \\
(0.326)\end{array}$ \\
\hline $\begin{array}{l}\text { Attitude: Children should } \\
\text { not be allowed to marry a } \\
\text { Dane }\end{array}$ & - & $\begin{array}{l}-0.177 \\
(0.133)\end{array}$ & $\begin{array}{l}-0.187 \\
(0.231)\end{array}$ & $\begin{array}{l}-0.416^{*} \\
(0.219)\end{array}$ & - & $\begin{array}{l}.0 .234 \\
(0.161)\end{array}$ & $\begin{array}{l}-0.230 \\
(0.235)\end{array}$ & $\begin{array}{l}-0.444 * \\
(0.239)\end{array}$ \\
\hline Constant term & $\begin{array}{l}-0.640 \\
(0.225)\end{array}$ & $\begin{array}{l}-0.434 \\
(0.240)\end{array}$ & $\begin{array}{l}-0.413 \\
(0.343)\end{array}$ & $\begin{array}{l}-0.262 \\
(0.342)\end{array}$ & $\begin{array}{l}-2.253 \\
(0.480)\end{array}$ & $\begin{array}{c}0.151 \\
(0.998)\end{array}$ & $\begin{array}{c}0.554 \\
(1.437)\end{array}$ & $\begin{array}{c}0.350 \\
(1.503)\end{array}$ \\
\hline Log likelihood & -758 & -351 & -179 & -157 & -359 & -355 & -184 & -158 \\
\hline Pseudo R-square & 0.110 & 0.207 & 0.231 & 0.253 & 0.189 & 0.199 & 0.211 & 0.252 \\
\hline No. of obs. & 621 & 640 & 336 & 304 & 640 & 640 & 336 & 304 \\
\hline
\end{tabular}

*** significant at a $1 \%$ level, $* *$ significant at a $5 \%$ level, * significant at a $10 \%$ level

1) Age at first marriage is instrumented. The predicted values from a tobit estimation with variable upper truncation are used instead of the observed age at first marriage, see Appendix C.

According to Tables 4 and 5, early marriage has a very negative effect on the chances of obtaining a qualifying education. For each year marriage is postponed, the chances of completing an education increase by about 2.2 percentage points. Since the average age at first marriage is 
very low for immigrants, about 19 years for Turks and 22 years for Pakistani and Ex-Yugoslavian immigrants, and 31 years for ethnic Danes, this is an important determinant of the low educational attainment of young immigrants from these countries. Comparing young ethnic Danes and Turkish immigrants, the age at first marriage may explain about $26 \%$ points of the gap of about 40 percentage points between young Danes and young Turkish immigrants.

Table 5. Marginal effects of a unit change selected explanatory variables from estimation of the probability of being enrolled or having completed a qualifying education - basic model. 1999. Probit specification (Std. err. in parentheses).

\begin{tabular}{lccc}
\hline & All & Men & Women \\
\hline Mother's education & $0.020^{* * *}$ & & 0.016 \\
& $(0.007)$ & $0.025^{* *}$ & $(0.010)$ \\
Age at immigration 0-6 year & 0.005 & $0.156^{*}$ & -0.138 \\
& $(0.006)$ & $(0.085)$ & $(0.086)$ \\
Age at first marriage & $0.022^{* * *}$ & $0.037^{* * *}$ & 0.009 \\
& $(0.008)$ & $(0.012)$ & $(0.013)$ \\
Language: Very good & $0.328^{* * *}$ & $0.226^{* * *}$ & $\left(0.413^{* * *}\right.$ \\
& $(0.048)$ & $(0.073)$ & $-0.352^{* *}$ \\
Neighbourhood: More than 5 immigrants & -0.188 & -0.059 & $(0.130)$ \\
in school class & $(0.116)$ & $(0.174)$ & $-0.168^{* *}$ \\
Married to a marriage migrant & -0.085 & -0.013 & $(0.084)$ \\
& $(0.058)$ & $(0.084)$ & $-0.194^{*}$ \\
Religion: Islam & $-0.145^{* *}$ & -0.127 & $(0.108)$ \\
& $(0.067)$ & $(0.093)$ & $-0.164^{*}$ \\
Attitude: Children should not be allowed & -0.079 & -0.074 & $(0.084)$ \\
to marry a Dane & $(0.060)$ & $(0.092)$ &
\end{tabular}

*** significant at a $1 \%$ level; ** significant at a $5 \%$ level, * significant at a $10 \%$ level.

1) Calculated at the mean value of the continuous explanatory variables. For the dummy variables, the marginal effect is calculated as the discrete change of the variable from 0 to 1 . The marginal effects are based on the model without IV-estimation, i.e. columns 2-4 in Table 4.

There seem to be differences between men and women with respect to the effect of age at first marriage, see also Appendix C, where the test of the instruments of age at first marriage is presented. When including different indicator variables representing attitudes and cultural norms (religion, married to a spouse who immigrated to Denmark because of the marriage, i.e. a marriage migrant, and the attitudes concerning own children's marriage behaviour), these variables are very significant for women, and they tend to purge away the effect of age at first marriage. For men these additional attitude variables are insignificant and do not affect in any notable way the effect from age at first marriage. Our interpretation of this result is that for 
women the decision to marry early is highly correlated with the variables reflecting norms and attitudes among the parents and the young immigrants concerning marriage, religion and family. It is not necessarily marriage in itself, which has a negative effect on women's educational attainment. It is a combination of these norms and attitudes and actual marriage behaviour, which has a large negative effect on the educational attainment. If these variables representing norms and attitudes are excluded from the estimation, the marginal effect from age at first marriage becomes highly significant and large (marginal effect becomes $5.1 \%$ compared to $0.9 \%$ in Table 5). For men, the story seems different. Here the norms and attitudes do not seem to prevent them from getting an education, but it is marriage in itself which has a negative effect. The explanation of this finding may be that norms and attitudes do not prevent young male immigrants from getting an education, but if they marry very early, they get family responsibilities and they may have to earn money for the family instead of investing in an education. Looking at the marginal effects in the ordered probit estimations, it appears that for the male immigrants, early marriage especially has a negative effect on the chances of obtaining a medium or long theoretic education. These are the educations which imply the largest amount of foregone earnings, i.e. they imply the largest investments, see Table B.2.

Age at immigration is only significant for men, not for women, in this study. This somewhat surprising result may be explained by the fact that there is a fairly limited variation in this variable because of the sample design. However, this result is probably caused by correlation between age at immigration and proficiency in Danish language. The younger the immigrants were at immigration, the better is their proficiency in the Danish language (Schmidt and Jakobsen, 2000). Proficiency in the Danish language is extremely important for the success in the educational system. The marginal effects in Table 5 show that being very good at Danish language increases the chance of completing a qualifying education by as much as $33 \%$ points compared to those who do not speak the Danish language fluently. The effect of a fluent language is largest for women for whom the marginal effect is $41 \%$, while for men it is 'only' $23 \%$. There are large differences between immigrant groups with respect to language proficiency. Turkish young immigrants are much less fluent in Danish language than Pakistani and Ex-Yugoslavian immigrants. Only about 46\% (55\%) of the young Turkish men(women) speak Danish very good, while these percentages are about $83 \%(80 \%)$ for Pakistani men (women) and 86\% (77\%) for ExYugoslavian men (women). Comparing for instance the Turkish and Ex-Yugoslavian men, these 
estimates 'explain' about $9 \%$ points $(23 \% *(86 \%-46 \%))$ of the educational gap between these two groups $(27 \%$ of the Turkish men and $68 \%$ of the Ex-Yugoslavian men had completed or were enrolled at an education in 1999).

A high fraction of immigrants at school and in the neighbourhood apparently has a negative effect on the female immigrants' success in the educational system, while it does not have any effect on the success of the male immigrants. This result is different from another Danish study on second generation immigrants, see Nielsen et al. (2001) who find that the negative ethnic concentration effect is mainly dominating for young males. The difference between the two studies may be explained by a different way of measuring ethnic concentration (we use a measure based on immigrants in childhood school class while Nielsen et al. (2001) use ethnic concentration in municipality).

In Table 6, we have tested the effects of additional variables. When the model in Table 4, column 2 , is extended with additional variables, one by one, the effects of the variables reported in Table 6 are fairly stable with one exception, mentioned below. Therefore, we only present the coefficients and marginal effects from the additional variables. Table 6 shows that beside the effect from the parents' (mothers') own educational level, the parents' attitude towards education is also extremely important: Immigrants, who have experienced that the parents were very interested in them getting an education, have a much higher chance (about 19\% for men and 30\% for women) of obtaining a qualifying education. The educational level of the mothers' and the parents' attitude to education are highly correlated, but despite this fact both variables are significant when they are included in the same model.

As described in Section 2, expectation of return migration may have different effects on investments in education. One effect may be that the immigrants do not want to invest as much in education in Denmark as ethnic Danes, because of transfer problems of the investments to the origin country. Another effect can be, that immigrants make investments, which are easy to transfer. The estimations presented in Table 6 show that the latter effect dominates for men, while return migration plans do not seem to affect women's decision concerning education. In the opposite direction, we find that for men, but not for women, having already got or having applied for a Danish Citizenship, the probability of being enrolled or having completed a qualifying 
education increases significantly.

Table 6. Coefficients from estimation of the probability of being enrolled or having completed a qualifying education - additional variables. ${ }^{1)}$ 1999. Probit specification. (Std. err. in parentheses).

\begin{tabular}{lcccccc}
\hline & \multicolumn{2}{c}{ All } & \multicolumn{2}{c}{ Men } & \multicolumn{2}{c}{ Women } \\
& Coefficient & Marg. Effect & Coefficient & Marg. Effect & Coefficient & Marg. Effect \\
\hline $\begin{array}{l}\text { Parents' attitude to education: } \\
\text { Education is very important }\end{array}$ & $0.558^{* * *}$ & $0.217^{* * *}$ & $0.482^{* *}$ & $0.189^{* *}$ & $0.786^{* * *}$ & $0.298^{* * *}$ \\
& $(0.154)$ & $(0.057)$ & $(0.237)$ & $(0.090)$ & $(0.228)$ & $(0.078)$ \\
Plan to return migrate & $0.339^{* *}$ & $0.129^{* *}$ & $0.381^{*}$ & $0.148^{*}$ & 0.337 & 0.133 \\
& $(0.161)$ & $(0.062)$ & $(0.231)$ & $(0.086)$ & 0.240 & $(0.093)$ \\
Have applied for or acquired & $0.295^{* *}$ & $0.109^{* *}$ & $0.564^{* * *}$ & $0.221^{* * *}$ & -0.013 & -0.005 \\
Danish citizenship & $(0.145)$ & $(0.057)$ & $(0.213)$ & $(0.080)$ & $(0.215)$ & $(0.086)$ \\
Felt discriminated against in & -0.152 & -0.061 & $-0.535^{* *}$ & $-0.209^{* *}$ & -0.024 & -0.009 \\
childhood & $(0.137)$ & $(0.055)$ & $(0.217)$ & $(0.087)$ & $(0.196)$ & $(0.073)$ \\
$\begin{array}{l}\text { Participated in mother tongue } \\
\text { courses in childhood }\end{array}$ & 0.052 & 0.021 & -0.039 & -0.016 & 0.380 & 0.151 \\
\hline
\end{tabular}

*** significant at a $1 \%$ level; ** significant at a $5 \%$ level, * significant at a $10 \%$ level

1) The additional variables are added to the models in columns $2-4$ in Table 4 one by one.

The discrimination index, which has a high value if the immigrant has experienced discrimination at basic school, has a significantly negative effect on men's probability of obtaining an education while for women the effect is not significant. Participation in mother-tongue courses has an insignificant and sometimes even negative coefficient. Thus, it does not seem to matter much whether the child has participated in mother-tongue courses. It is obvious that the indicator for mother-tongue courses is a fairly rough measure which does not take into account duration and quality of the courses.

\subsection{Drop-outs from the educational system}

Table 3 revealed large differences between the young immigrants with respect to their drop-out rates from the educational system. In this section, we analyse whether these differences are explained by observed differences in parental capital, language proficiency etc. or the differences remain significant between countries (and gender) when controlling for these differences in background characteristics. We estimate a probit model of the individual drop-out rate, conditional on having been enrolled at an education. Thus, we restrict the sample to a selected group, and the selection varies across countries and gender, since for instance only about half of 
the Turkish men have ever enrolled at an education. Further, since the number of observations is fairly low when estimating drop-out rates, we restrict the model to relatively few variables in order to save degrees of freedom, and we are not able estimate country-specific relations.

Table 7. Coefficients from estimation of the probability of dropping out from an education, conditional on having been enrolled at a qualifying education. 1999. Probit specification. (Std. err. in parentheses).

\begin{tabular}{|c|c|c|c|c|c|c|}
\hline & \multicolumn{2}{|c|}{ All } & \multicolumn{2}{|c|}{ Men } & \multicolumn{2}{|c|}{ Women } \\
\hline & Coeffic. & Marg. eff. & Coeffic. & Marg. eff. & Coeffic. & Marg. eff. \\
\hline Age and country-specific indicators & insignificant & insignificant & insignificant & insignificant & insignificant & insignificant \\
\hline Woman & $\begin{array}{c}-0.345 * * \\
(0.144)\end{array}$ & $\begin{array}{c}-0.102 * * \\
(0.042)\end{array}$ & - & - & - & - \\
\hline Mother's education & $\begin{array}{l}-0.034^{*} \\
(0.021)\end{array}$ & $\begin{array}{l}-0.010^{*} \\
(0.006)\end{array}$ & $\begin{array}{l}-0.038 \\
(0.028)\end{array}$ & $\begin{array}{l}-0.012 \\
(0.009)\end{array}$ & $\begin{array}{l}-0.039 \\
(0.033)\end{array}$ & $\begin{array}{l}-0.010 \\
(0.008)\end{array}$ \\
\hline Age at immigration $0-6$ years & $\begin{array}{c}0.094 \\
(0.185)\end{array}$ & $\begin{array}{c}0.028 \\
(0.055)\end{array}$ & $\begin{array}{l}-0.327 \\
(0.249)\end{array}$ & $\begin{array}{l}-0.108 \\
(0.083)\end{array}$ & $\begin{array}{c}-0.701 * * \\
(0.318)\end{array}$ & $\begin{array}{c}-0.159 * * \\
(0.064)\end{array}$ \\
\hline Age at first marriage & $\begin{array}{c}-0.047 * * \\
(0.024)\end{array}$ & $\begin{array}{c}-0.014 * * \\
(0.007)\end{array}$ & $\begin{array}{c}-0.074 * * \\
(0.030)\end{array}$ & $\begin{array}{c}-0.024 * * \\
(0.098)\end{array}$ & $\begin{array}{l}-0.033 \\
(0.044)\end{array}$ & $\begin{array}{l}-0.008 \\
(0.011)\end{array}$ \\
\hline Language: Very good & $\begin{array}{c}-0.506 * * * \\
(0.189)\end{array}$ & $\begin{array}{c}-0.170 * * * \\
(0.067)\end{array}$ & $\begin{array}{l}-0.237 \\
(0.245)\end{array}$ & $\begin{array}{l}-0.081 \\
(0.087)\end{array}$ & $\begin{array}{c}-0.891 * * * \\
(0.315)\end{array}$ & $\begin{array}{c}-0.285^{* * *} \\
(0.115)\end{array}$ \\
\hline $\begin{array}{l}\text { Neighbourhood: More than } 5 \\
\text { immigrants in school class }\end{array}$ & $\begin{array}{c}0.214 \\
(0.441)\end{array}$ & $\begin{array}{c}0.069 \\
(0.152)\end{array}$ & $\begin{array}{l}-0.039 \\
(0.551)\end{array}$ & $\begin{array}{l}-0.013 \\
(0.183)\end{array}$ & $\begin{array}{c}1.009 \\
(0.836)\end{array}$ & $\begin{array}{c}0.348 \\
(0.330)\end{array}$ \\
\hline Constant term & $\begin{array}{c}0.703 \\
(0.604)\end{array}$ & - & $\begin{array}{c}0.366 \\
(0.418)\end{array}$ & - & $\begin{array}{c}-0.613 \\
(0.444)\end{array}$ & - \\
\hline Log likelihood & \multicolumn{2}{|c|}{-222} & \multicolumn{2}{|c|}{-129} & \multicolumn{2}{|c|}{-83.5} \\
\hline Pseudo R-square & \multicolumn{2}{|c|}{0.081} & \multicolumn{2}{|c|}{0.012} & \multicolumn{2}{|c|}{0.093} \\
\hline No. of obs. & \multicolumn{2}{|c|}{435} & \multicolumn{2}{|c|}{246} & \multicolumn{2}{|c|}{189} \\
\hline
\end{tabular}

*** indicates significant at a $1 \%$ level, $* *$ significant at a $5 \%$ level, * significant at a $10 \%$ level.

With these reservations in mind, the estimations in Table 7, column 1, show that women have a significantly lower drop-out rate than men. When including information on observed background characteristics, the country-specific indicators turn out as insignificant. The high drop-out rates for especially Turkish men, see Table 3, seem to be explained by a low level of parental capital (mother's education), poor language proficiency and a low age at first marriage. When including country-specific indicators, the educational level of the mothers and language proficiency are not significant for men. However, when the country-specific indicators are excluded, the mothers' educational level and language proficiency turn out to have significantly negative effects on the risk of dropping out. The indicator for Turkish immigrants partly picks 
up the negative effects of Turkish mothers' very low educational level and a much lower level of language proficiency among Turkish immigrants compared to the other groups.

\subsection{Why does educational attainment differ between immigrant groups - different coefficients or different characteristics?}

As described in Section 5, there are large variations in the educational attainment of the three groups studied in this analysis. Turks have a much lower educational level than Pakistani and ExYugoslavian immigrants, and there are also notable differences between young men and women. In order to look more deeply into the overall reasons for these differences and to split the differences into a component reflecting coefficients (behaviour) and component representing characteristics (explanatory variables), we have re-estimated the basic model from Table 4, column 2 , but now for subgroups of immigrants. ${ }^{8}$ The results from estimating country-specific models of the probability of being enrolled or having completed a qualifying education are shown in Table 8.

Table 8 indicates both similarities and differences between the three countries with respect to the factors that explain whether a young immigrant is enrolled or has completed a qualifying education. A common pattern is the very large influence from language proficiency. A very good language proficiency increases the probability of having completed or being enrolled at a qualifying education by about $31 \%$ for Turkish immigrants, $23 \%$ for Pakistani immigrants, and as much as $41 \%$ for Ex-Yugoslavian immigrants.

When estimating country-specific relations, the educational level of the mother and age at first marriage are much less significant. One reason is that the number of observations is small. But part of the drop of significance may also be that within the groups from the three countries there is much less variation than across groups in these explanatory variables, and therefore the standard errors of estimated coefficients increase.

\footnotetext{
${ }^{8}$ Ideally we would like to estimate 6 country- and gender-specific relations, but the number of observations is not large enough for estimating on these subgroups.
} 
Turkish women have a significantly higher chance of completing an education when controlling for other background characteristics, while the gender coefficient is not significant for the two other countries. For Pakistani immigrants, the age at first marriage has a positive effect on the chances of completing an education with marginal effects of $2.5 \%$. The educational level of the mother has a significant effect on Pakistani and Ex-Yugoslavian immigrants' chances of getting an education. None of these variables are significant for Turkish immigrants when estimating a country-specific relation.

Table 8. Coefficients from estimation of the probability of being enrolled or having completed a qualifying education - basic model. Separate immigrant groups. 1999. Probit specification. (Std. err. in parentheses)

\begin{tabular}{|c|c|c|c|c|c|c|}
\hline & \multicolumn{2}{|c|}{ Turkey } & \multicolumn{2}{|c|}{ Pakistan } & \multicolumn{2}{|c|}{ Ex-Yugoslavia } \\
\hline & Coefficient & Marg. Effect & Coefficient & Marg. Effect & Coefficient & Marg. Effect \\
\hline $\begin{array}{l}\text { Age indicator, age at } \\
\text { immigrations, neighbourhood } \\
\text { variable }\end{array}$ & insignificant & insignificant & insignificant & insignificant & insignificant & insignificant \\
\hline Woman & $\begin{array}{l}0.362^{*} \\
(0.200)\end{array}$ & $\begin{array}{l}0.123^{*} \\
(0.67)\end{array}$ & $\begin{array}{c}0.041 \\
(0.214)\end{array}$ & $\begin{array}{c}0.046 \\
(0.080)\end{array}$ & $\begin{array}{l}-0.320 \\
(0.223)\end{array}$ & $\begin{array}{l}-0.117 \\
(0.081)\end{array}$ \\
\hline Mother's education & $\begin{array}{c}0.069 \\
(0.051)\end{array}$ & $\begin{array}{c}0.024 \\
(0.017)\end{array}$ & $\begin{array}{l}0.042 * \\
(0.025)\end{array}$ & $\begin{array}{l}0.016^{*} \\
(0.009)\end{array}$ & $\begin{array}{l}0.051^{*} \\
(0.030)\end{array}$ & $\begin{array}{l}0.019^{*} \\
(0.011)\end{array}$ \\
\hline Age at first marriage & $\begin{array}{c}0.055 \\
(0.036)\end{array}$ & $\begin{array}{c}0.019 \\
(0.012)\end{array}$ & $\begin{array}{l}0.069^{*} \\
(0.037)\end{array}$ & $\begin{array}{l}0.025^{*} \\
(0.013)\end{array}$ & $\begin{array}{c}0.046 \\
(0.044)\end{array}$ & $\begin{array}{c}0.017 \\
(0.016)\end{array}$ \\
\hline Language: Very good & $\begin{array}{c}0.938^{* * *} \\
(0.205)\end{array}$ & $\begin{array}{c}0.311^{* * * *} \\
(0.063)\end{array}$ & $\begin{array}{c}0.607 * * \\
(0.258)\end{array}$ & $\begin{array}{c}0.234 * * \\
(0.100)\end{array}$ & $\begin{array}{l}1.080 * * * \\
(0.324)\end{array}$ & $\begin{array}{c}0.411^{* * *} \\
(0.124)\end{array}$ \\
\hline Married to a marriage migrant & $\begin{array}{l}-0.010 \\
(0.246)\end{array}$ & $\begin{array}{l}-0.003 \\
(0.084)\end{array}$ & $\begin{array}{l}-0.236 \\
(0.254)\end{array}$ & $\begin{array}{l}-0.089 \\
(0.097)\end{array}$ & $\begin{array}{c}-0.827 * * \\
(0.329)\end{array}$ & $\begin{array}{c}-0.318^{* *} \\
(0.124)\end{array}$ \\
\hline Religion: Islam & $\begin{array}{c}-0.971 * * \\
(0.333)\end{array}$ & $\begin{array}{c}-0.368 * * * \\
(0.125)\end{array}$ & $\begin{array}{l}1.120^{* *} \\
(0.444)\end{array}$ & $\begin{array}{r}0.422 * * \\
(0.142)\end{array}$ & $\begin{array}{l}-0.503 * \\
(0.258)\end{array}$ & $\begin{array}{l}-0.191^{*} \\
(0.100)\end{array}$ \\
\hline $\begin{array}{l}\text { Attitude: Children should not } \\
\text { be allowed to marry a Dane }\end{array}$ & $\begin{array}{c}0.224 \\
(0.222)\end{array}$ & $\begin{array}{l}-0.074 \\
(0071)\end{array}$ & $\begin{array}{l}-0.257 \\
(0.253)\end{array}$ & $\begin{array}{l}-0.097 \\
(0.097)\end{array}$ & $\begin{array}{l}-0.730 \\
(0.578)\end{array}$ & $\begin{array}{l}-0.284 \\
(0.220)\end{array}$ \\
\hline Constant term & $\begin{array}{l}-0.109 \\
(0.421)\end{array}$ & - & $\begin{array}{l}-1.171 \\
(0.575)\end{array}$ & - & $\begin{array}{l}-0.214 \\
(0.441)\end{array}$ & - \\
\hline Log likelihood & \multicolumn{2}{|c|}{-125} & \multicolumn{2}{|c|}{-117} & \multicolumn{2}{|c|}{-91.3} \\
\hline Pseudo R-square & \multicolumn{2}{|c|}{0.189} & \multicolumn{2}{|c|}{0.138} & \multicolumn{2}{|c|}{0.257} \\
\hline No. of obs. & \multicolumn{2}{|c|}{246} & \multicolumn{2}{|c|}{207} & \multicolumn{2}{|c|}{187} \\
\hline
\end{tabular}

$* * *$ significant at a $1 \%$ level, $* *$ significant at a $5 \%$ level, $*$ significant at a $10 \%$ level

The effect of religion is interesting. For Turkish immigrants, the coefficient for being Islamic is significantly negative and the marginal effect is numerically very large, $37 \%$, while for the 
Pakistani immigrants the marginal effect is also very large (42\%), but with the opposite sign! Thus, Islamic religion seems to hinder Turkish young people from getting an education while exactly the opposite holds for Pakistani immigrants. For Ex-Yugoslavian immigrants the marginal effect of having an Islamic religion is $-19 \%$, i.e. negative. Almost all young immigrants from Pakistan (about 95\%) have an Islamic religion, see Appendix Table A, while for Turks this figure is $90 \%$ and for Ex-Yugoslavian immigrants $22 \%$. The effect of being married to a marriage migrant is significantly negative for only Ex-Yugoslavians. However, fewer Ex-Yugoslavian marry a marriage migrant (about $28 \%$ ), while a much larger proportion of young immigrants from Turkey and Pakistan marry a spouse who migrate to Denmark because of the marriage $(61 \%$ from Turkey and 37\% from Pakistan).

Since the observed patterns concerning educational attainment in Table 1 are the results of differences in observed characteristics as well as differences in estimated coefficients, it may be interesting to split the observed gap between immigrant groups into a component reflecting differences in background characteristics and a component reflecting differences in coefficients. ${ }^{9}$ Further, it is interesting to compare these findings with young Danes' behaviour and characteristics. Usually, a Blinder-Oaxaca decomposition is used for this purpose, when the estimated model is a least square model, see for instance Oaxaca (1973) but this method does not immidiately apply when using a maximum-likelihood estimator. Instead, we calculate the predicted probabilities of completing or being enrolled at a qualifying education and mix coefficients and the average characteristics from the three immigrant countries and Denmark. The results are shown in Table 9. For Denmark we are not able to estimate a model comparable to the model estimated for the three immigrant countries, and therefore we do not have Danish coefficients, but only Danish characteristics in Table $9 .{ }^{10}$ The variables age at immigration, neighbourhood, married to a marriage migrant, Islamic religion, and attitude: children should not

\footnotetext{
${ }^{9}$ The coefficient component is sometimes called the discrimination component or a component reflecting differences in 'behaviour'. Since we include a number of attitudinal variables as background characteristics, which also reflect 'behaviour', we prefer not to interpret the coefficient component as a 'behavioural component'.

${ }^{10}$ The predicted probabilities are based on the average characteristics for the country concerned. This means that the predicted values for 'own X-vector' and 'own $\beta$-vector' are not equal to the predicted = observed probabilities, since the distribution of the X-values matters because of the non-linearity of the model. As an alternative, we might have predicted the probabilities based on individual X-values for comparison country and assumed the same distribution of X-values as in either own country or the comparison country. However, this opens up for a number of new decompositions and complicates the calculations considerably.
} 
be allowed to marry a Dane are set to 0 for a Dane, and the variable language proficiency is set to 1 (perfect language). We do not show the components for the single explanatory variables because of the strong correlation between some of the explanatory variables may imply that the estimated components for separate variables become a bit arbitrary.

When comparing the results in the first 3 columns of Table 9 with the figures in column 4 which are based on the average background characteristics of Danish youth and immigrant coefficients for immigrants, we get the very interesting result that Danish youth would have had a much higher predicted probability of having completed a qualifying education in either of the three hypothetical cases compared to the observed probability for Danes. Thus, we can conclude based on these results that the lower educational attainment, especially for Turkish immigrants and to a smaller extent the other groups is mainly due to unfavourable background characteristics, including the variables reflecting religion, marriage behaviour and attitude concerning marriage behaviour. The estimated coefficients of immigrants are not in themselves unfavourable with respect increasing the chances of completing a qualifying education.

Table 9. Predicted hypothetical probabilities of completing or being enrolled at a qualifying education, evaluated at coefficients and average characteristics from different countries.

Average characteristics $(\mathbf{X})$ from:

\begin{tabular}{llcccc} 
& & Turkey & Pakistan & $\begin{array}{c}\text { Ex- } \\
\text { Yugoslavia }\end{array}$ & Denmark ${ }^{1)}$ \\
\hline Behaviour $(\beta$-coefficients) from: & Turkey & 0.29 & 0.49 & 0.79 & 0.99 \\
& $\begin{array}{l}\text { Pakistan } \\
\text { Ex-Yugoslavia }\end{array}$ & 0.15 & 0.41 & 0.65 & 0.99 \\
\hline $\begin{array}{l}\text { Predicted probability at own } \\
\begin{array}{l}\text { individual X and } \beta \text { values } \\
\text { (observed probability) }\end{array}\end{array}$ & $0.29(0.32)$ & $0.65(0.63)$ & $0.66(0.65)$ & 0.72 \\
\hline
\end{tabular}

* Calculations are based on results in Table 8 .

1) The following characteristics from young Danes are included in the prediction: Age, mother's education, age at first marriage, gender, language proficiency=very good, and age at migration is set to 1 year. The variables married to a marriage migrant, attitude: Children should not be allowed to marry a Dane and Muslim religion are set to 0 for Danes for whom we do not have any information on these survey questions. Therefore, the predicted value for Danes is not equal to the observed value for Danes, which is given in column 4 , row 3.

According to Table 9, the educational attainment of young immigrants from Turkey would have been much more successful if Turks had the behaviour of young Pakistanis. On the other hand, applying the behaviour of young Ex-Yugoslavians would further reduce the probability of getting 
an education for the young Turks, especially because of the very negative language proficiency effect for Ex-Yugoslavians combined with the relatively low proportion of Turkish immigrants who are fluent in Danish.

The coefficients of young Pakistanis are more positive with respect to getting an education than the coefficients of the Turkish immigrants, since applying Pakistani coefficients to Turkish background characteristics increases the predicted probability of Turkish immigrants compared to using Turkish coefficients (39\% against 29\%), and doing the opposite Turkish coefficients and Pakistani characteristics reduce the probability compared to the Pakistani coefficients (49\% against $65 \%$ ). For the Ex-Yugoslavians, the fairly high probabilities are the result of fairly 'favourable' background characteristics (mother has relatively high educational level, low age at immigration and good language proficiency) more than 'favourable' coefficients. If Pakistani or Turkish young immigrants had Ex-Yugoslavian behaviour, the predicted probabilities would decrease substantially for these groups. ${ }^{11}$

\section{Conclusion}

The educational attainment of young immigrants in Denmark is lacking behind the level of young native Danes. This paper analyses which factors are important in explaining the fairly low educational attainment for some immigrant groups. We focus on the children of guest workers from Turkey, Pakistan and Ex-Yugoslavia aged 28-36 years in 1999. All three groups have lower probabilities of being enrolled or having completed a qualifying education compared to young native Danes, but there are also large differences between the three immigrant groups. About $54 \%$ of the young Pakistani immigrants and 53\% of the Ex-Yugoslavian immigrants in this study have completed a qualifying education. The same figure for Danes in the same age group is $68 \%$. Pakistani immigrants tend to get a higher (longer) education than the other two groups.

Young Turks, especially the young Turkish men, have a very low probability of being enrolled at or completing an education. Only $26 \%$ of the Turkish men and women who were aged $28-36$

\footnotetext{
${ }^{11}$ One result seems puzzling, the 39\% reflecting Pakistani coefficients and Ex-Yugoslavian characteristics. Here the very positive effect from an Islamic religion for Pakistani explains the result, since fairly few Ex-Yugoslavians have an Islamic religion. Therefore the very negative constant term in the Pakistani relation gets a considerable weight when computing the counterfactual.
} 
when they were observed in 1999 had completed a qualifying education. When adding the persons who were still enrolled in the educational system, this figure increases to about $31 \%$ which is still much lower than the same figures for the Pakistani immigrants (63\%) and ExYugoslavian immigrants (61\%).

One reason for the low educational attainment of young Turkish immigrants is high drop-out rates which again seem to be the result of language problems and a very low level of parental capital (mother's education). Another explanation of the high drop-out rates is that immigrants, especially from Turkey, marry at a very young age. On average, age at first marriage is 20.4 years for males and 19.1 years for females from Turkey. For the other two immigrant groups, the age at first marriage is 2-3 years higher, and for Danes it is 31 years. The analyses of the determinants of having completed or being enrolled at a qualifying education show the same patterns as the drop-out rates, i.e. parental capital, language proficiency and age at first marriage are very important determinants of the success of young immigrants. However, for women, the effect of early marriage is strongly related to other variables reflecting attitudes and norms in the family concerning marriage behaviour and religion, and it may not marriage in itself, but different cultural factors which are the main explanation of the lower educational attainment of young immigrant women. For men these cultural factors do not seem to hinder them in getting an education.

Other factors are also found to be important for the educational attainment of young immigrants. Among these are the attitude of the parents concerning the importance of getting an education. If the parents find that it is important for the children to get an education, after controlling for the educational level of the parents, language proficiency etc., there is a much higher probability that the child gets a qualifying education compared to children who have parents who do not find that education is important. Attending mother-tongue courses in the childhood is not found to have any positive or negative effects on the educational attainment of young immigrants in this study.

When simulating counterfactual probabilities of completing or being enrolled at a qualifying education based on average observed characteristics for Danish youth but applying the coefficients for one of the three countries included in this study, we get the interesting result that Danish youth would have had much a higher predicted probability of having completed a 
qualifying education in either of the three hypothetical cases compared to the observed probability for Danes. Thus, the lower educational attainment, especially for Turkish immigrants and to a smaller extent the other groups, is mainly due to unfavourable background characteristics.

The conclusion from this study may look fairly pessimistic from one perspective. Despite large investments in the Danish educational system, an almost free educational system from basic school to university level, free mother-tongue language courses in all municipalities etc., there are still very large differences between the educational attainment of young native Danes and immigrants. It is very important to 'improve' the background characteristics of the young immigrants. There is probably not much to do about factors like parental capital and age at immigration. On the other hand, the study also points at very important factors which are not impossible to affect by various policy instruments and improved information to the immigrant families on the importance of education, for instance parents' attitudes towards education, Danish language proficiency and marriage behaviour.

\section{References}

Becker, G. S. and N. Tomes (1979), An Equilibrium Theory of the Distribution of Income and Intergenerational Mobility, Journal of Political Economy 87, 1153-1189.

Björklund, A. and M. Jäntti (1997), Intergenerational income mobility in Sweden compared to the United States, American Economic Review, vol 87, 144-151.

Board for Ethnic Equality (1996), The Situation regarding Trainee Jobs for Ethnic Minorities (in Danish), The Board of Ethnic Equality, Copenhagen.

Borjas, G. J. (1992), Ethnic Capital and Intergenerational Mobility, Quarterly Journal of Economics, vol. 107(1), $123-150$

Borjas, G. J. (1993), The Intergenerational Mobility of Immigrants, Journal of Labour Economics, vol. 11(1), 113135.

Borjas, G. J. (1994), Immigrants skills and ethnic spillovers, Journal of Population Economics, 7 (2), 99-118

Borjas, G. J. (1995), Ethnicity, Neighbourhoods, and Human Capital Externalities, American Economic Review, vol. $85,365-390$.

Bound, J, Jaeger, D.A. and R. Baker (1995), Problems with instrumental variables estimation when the correlation between the instruments and the endogenous explanatory variable is weak, Journal of American Statistical Association 90 (430), pp. 443-450.

Cahan, S., D. Davis and R. Staub (2001), Age at Immigration and Scholastic Achievement in School-Age Children: Is there a Vulnerable Age?, International Migration Review, Vol 35, 587-595. 
Cain, G. (1986), The Economic Analysis of Labor Market discrimination: A Survey, in O. C. Ashenfelter and R. Layard (eds.), Handbook of Labour Economics, Vol I, North Holland, Amsterdam.

Card, D., J. DiNardo and E. Estes (1998), The more things change: Immigrants and the children of immigrants in the 1940s, the 1970s, and the 1990s, NBER working paper 6519, National Bureau of Economic Research, Massachusetts.

Chiswick, G. (1988), Differences in Education and Earnings across Racial and Ethnic Groups: Tastes, Discrimination, and Child Quality, The Quarterly Journal of Economics, 571-597.

Coleman, J. S. (1988), Social Capital in the Creation of Human Capital, American Journal of Sociology, vol XCIV, S95-120.

Dennild, K., (2000), Modersmålslærere og tolke som integrerede medarbejdere ved sprogcentrene, in 'På Sporet', Danish Ministry of Education, Copenhagen.

Duignan, P. (1998), Bilingual Education: A Critique, Hoover Essay 9/98, Hoover Institution.

Dustmann, C. (2001a), Return Migration, Wage Differentials, and the Optimal Migration Duration, IZA Discussion Paper, No. 264, IZA, Bonn.

Dustmann (2001b), Parental Backgound, Primary to Secondary School Transitions, and Wages, IZA Discussion Paper No. 367, IZA, Bonn.

Ekberg, J. (1997), Hur är arbetsmarknaden för den andra generationens invandrare?, Arbetsmarknad \& Arbetsliv, vol. 3 (2), 5-16.

Gang, I. and C. Zimmermann (2000), Is Child like Parent? Educational Attainment and Ethnic Origin, The Journal of Human Resources 35 (3), 550-569.

Ginther, D., R. Haveman and B. Wolfe (2000), Neighborhood Attributes as Determinants of Children's Outcomes, The Journal of Human Resources, XXXV, 4, 603-642.

Haveman, R. and B. W olfe (1995), The Determinants ofChildren's Attainments: A Review of Methods and Findings, Journal of Economic Literature XXXIII, 4, 1829-1878.

Hummelgaard, H., B. K. Graversen, L. Husted and J. B. Nielsen (1998), Education and unemployment among young immigrants (in Danish), AKF rapport, AKF forlaget, Copenhagen.

Husted, L., H. S. Nielsen, M. Rosholm and N. Smith (2001), Employment and Wage Assimilation of Male First Generation Immigrants in Denmark, International Journal of Manpower, vol. 22, 39-68.

Just Jeppesen, K. (1989), Young immigrants (in Danish), Socialforskningsinstituttet 89:6, Copenhagen.

Lazear, E. P (1999), Culture and Language, Journal of Political Economy, 107 (S6), S95-129.

Ministry of Education (2001), First and Second Generation Immigrants in the Educational System (in Danish), Undervisningsministeriets Forlag, Copenhagen.

Nielsen, H. S., M. Rosholm, N. Smith and L. Husted (2001), Intergenerational Transmissions and the School to Work Transition of $2^{\text {nd }}$ Generation Immigrants, IZA Discussion Paper 296, IZA, Bonn.

Oaxaca, R. (1973), Male-Female Wage Differentials in Urban Labour Markets, International Economic Review, 14 , 693-709.

Riphahn, R. (2001), Cohort Effects in the Educational Attainment of Second Generation Immigrants in Germany: 
An Analysis of Census Data, IZA Discussion Paper 291, IZA, Bonn.

Rosholm, M., L. Husted and H. S. Nielsen (2002), Integration Across Generations? The Education of Second Generation Immigrants, mimeo, Aarhus School of Business.

Schaafsma, J. and A. Sweetman (2001), Immigrant Earnings: Age at immigration matters, Canadian Journal of Economics, vol. 34, no. 4, 1066-99.

Schmidt, G. and V. Jakobsen (2000), 20 years in Denmark (in Danish), Socialforskningsinstituttet 00:11, Copenhagen.

Solon, G. (1999), Intergenerational mobility in the labour market, in Ashenfelter, O. and D. Card (eds.), Handbook of Labour Economics, Vol 3, Elsevier.

Trostel, P, i. Walker and P. Woolley (2002), Estimates of the economic return to schooling for 28 countries, Labour Economics, Vol. 9 (1), pp. 1-16.

Österberg, T. (2000), Economic Perspectives on Immigrants and Intergenerational Transmissions, Ekonomiska Studier 102, Göteborgs Universitet, Sweden.

Van Ours, J. C. and J. Veenman (2001), The Educational Attainment of Second Generation Immigrants in the Netherlands, IZA Discussion Paper no. 297, IZA, Bonn. 


\section{Appendix A}

Table A. Sample means and standard errors in parentheses. 1999. Sample sizes for the calculated variable is given in square brackets.

\begin{tabular}{|c|c|c|c|c|c|c|}
\hline & \multicolumn{2}{|c|}{ Turkey } & \multicolumn{2}{|c|}{ Pakistan } & \multicolumn{2}{|c|}{ Ex-Yugoslavia } \\
\hline & Men & Women & Men & Women & Men & Women \\
\hline \multicolumn{7}{|l|}{ Education: } \\
\hline Length of (completed) formal education [N=693] & $10.4(3.0)$ & $9.6(3.5)$ & $12.8(3.3)$ & $12.1(2.8)$ & $11.9(2.6)$ & $11.3(3.0)$ \\
\hline $\begin{array}{l}\text { Length of (completed or ongoing) formal education } \\
\mathrm{N}=693]\end{array}$ & $10.4(3.0)$ & $10.1(3.7)$ & $13.3(3.3)$ & $12.5(3.1)$ & $12.2(2.7)$ & $11.6(3.2)$ \\
\hline \multicolumn{7}{|l|}{ Information on parents and childhood: } \\
\hline Length of father's education, years [N=638]: & $3.2(2.8)$ & $3.3(3.0)$ & $9.4(4.7)$ & $10.7(4.4)$ & $7.6(4.3)$ & $7.5(4.4)$ \\
\hline Length of mother's education, years [N=650] & $1.7(1.9)$ & $1.2(2.0)$ & $4.7(4.0)$ & $5.4(4.2)$ & $6.2(4.0)$ & $6.6(4.3)$ \\
\hline $\begin{array}{l}\text { Parents' attitude is positive concerning the following } \\
\text { questions: } \\
\text { Education is important }[\mathrm{N}=693] \\
\text { Child should return migrate }[\mathrm{N}=693] \\
\text { Child should marry early }[\mathrm{N}=693]\end{array}$ & $\begin{array}{l}0.722(0.450) \\
0.143(0.351) \\
0.270(0.446)\end{array}$ & $\begin{array}{l}0.549(0.499) \\
0.053(0.224) \\
0.188(0.392)\end{array}$ & $\begin{array}{l}0.933(0.250) \\
0.119(0.324) \\
0.163(0.371)\end{array}$ & $\begin{array}{l}0.907(0.292) \\
0.047(0.212) \\
0.105(0.308)\end{array}$ & $\mid \begin{array}{l}0.806(0.397) \\
0.107(0.310) \\
0.078(0.269)\end{array}$ & $\begin{array}{l}0.791(0.409) \\
0.064(0.245) \\
0.064(0.245)\end{array}$ \\
\hline From rural area in origin country $[\mathrm{N}=668]$ & $0.702(0.459)$ & $0.727(0.447)$ & $0.368(0.484)$ & $0.337(0.476)$ & $0.490(0.502)$ & $0.562(0.499)$ \\
\hline High proportion of immigrants at school $[\mathrm{N}=514]^{1)}$ & $0.040(0.196)$ & $0.078(0.269)$ & $0.063(0.244)$ & $0.016(0.126)$ & $0.048(0.216)$ & $0.041(0.199)$ \\
\hline $\begin{array}{l}\text { Attended courses in mother-tongue language in } \\
\text { childhood }[\mathrm{N}=529]\end{array}$ & $0.832(0.376)$ & $0.757(0.431)$ & $0.720(0.721)$ & $0.769(0.425)$ & $0.703(0.460)$ & $0.636(0.484)$ \\
\hline \multicolumn{7}{|l|}{ Own demographic and other characteristics: } \\
\hline Age $[\mathrm{N}=693]$ & $32.1(2.6)$ & $31.9(2.4)$ & $31.5(2.2)$ & $31.2(2.2)$ & $32.1(2.2)$ & $32.2(2.4)$ \\
\hline Age28-30 [N=693] & $0.302(0.461)$ & $0.338(0.474)$ & $0.437(0.498)$ & $0.477(0.502)$ & $0.252(0.436)$ & $0.300(0.460)$ \\
\hline Age $31-33[\mathrm{~N}=693]$ & $0.349(0.479)$ & $0.376(0.486)$ & $0.341(0.476)$ & $0.384(0.489)$ & $0.437(0.498)$ & $0.381(0.488)$ \\
\hline Age at immigration $[\mathrm{N}=693]$ & $8.2(4.0)$ & $7.5(3.9)$ & $6.1(3.3)$ & $5.7(3.2)$ & $4.8(3.4)$ & $5.1(3.4)$ \\
\hline Age at immigration $0-6$ years & $0.294(0.457)$ & $0.368(0.484)$ & $0.555(0.499)$ & $0.640(0.482)$ & $0.747(0.436)$ & $0.682(0.468)$ \\
\hline Number of children $[\mathrm{N}=693]$ & $2.2(1.2)$ & $2.3(1.1)$ & $1.8(1.3)$ & $1.9(1.3)$ & $1.4(1.1)$ & $1.8(1.1)$ \\
\hline Age at first marriage - $1999[\mathrm{~N}=517]$ & $20.4(3.1)$ & $19.1(2.8)$ & $23.6(3.6)$ & $21.2(2.9)$ & $23.2(3.5)$ & $21.1(4.0)$ \\
\hline Applied for or acquired Danish citizenship [N=693] & $0.666(0.473)$ & $0.729(0.446)$ & $0.933(0.250)$ & $0.907(0.292)$ & $0.786(0.411)$ & $0.745(0.438)$ \\
\hline $\begin{array}{l}\text { Danish language proficiency, evaluation by } \\
\text { interviewer: } 1=\text { very good,...,5=bad }[\mathrm{N}=682]\end{array}$ & $1.776(0.860)$ & $1.815(1.040)$ & $1.207(0.505)$ & $1.306(0.724)$ & $1.198(0.567)$ & $1.245(0.474)$ \\
\hline Language very good & $0.456(0.500)$ & $0.546(0.500)$ & $0.830(0.377)$ & $0.800(0.402)$ & $0.861(0.347)$ & $0.774(0.420)$ \\
\hline Plan to return to origin country $[\mathrm{N}=693]$ & $0.230(0.423)$ & $0.173(0.380)$ & $0.126(0.333)$ & $0.151(0.360)$ & $0.097(0.298)$ & $0.045(0.209)$ \\
\hline Many ethnic Danish friends in 1988 [N=529] & $0.178(0.385)$ & $0.234(0.425)$ & $0.288(0.455)$ & $0.246(0.434)$ & $0.469(0.503)$ & $0.558(0.500)$ \\
\hline $\begin{array}{l}\text { The marriage is arranged by another person than the } \\
\text { migrant - } 1988[\mathrm{~N}=529]\end{array}$ & $0.158(0.367)$ & $0.234(0.425)$ & $0.153(0.362)$ & $0.477(0.503)$ & $0.016(0.125)$ & $0.013(0.114)$ \\
\hline $\begin{array}{l}\text { Feel more Danish than Turkish/Pakistani/Yugoslavian } \\
\text {-1988 }[\mathrm{N}=529]\end{array}$ & $0.198(0.400)$ & $0.126(0.333)$ & $0.243(0.431)$ & $0.231(0.425)$ & $0.422(0.498)$ & $0.338(0.476)$ \\
\hline
\end{tabular}




\begin{tabular}{|c|c|c|c|c|c|c|}
\hline & \multicolumn{2}{|c|}{ Turkey } & \multicolumn{2}{|c|}{ Pakistan } & \multicolumn{2}{|c|}{ Ex-Yugoslavia } \\
\hline & Men & Women & Men & Women & Men & Women \\
\hline Religion is very important in 1988 [N=529] & $0.446(0.500)$ & $0.495(0.502)$ & $0.649(0.480)$ & $0.769(0.425)$ & $0.078(0.270)$ & $0.104(0.307)$ \\
\hline Muslim religion $[\mathrm{N}=693]$ & $0.921(0.271)$ & $0.887(0.318)$ & $0.919(0.275)$ & $1.000(0.000)$ & $0.243(0.431)$ & $0.209(0.409)$ \\
\hline The spouse is from the same family - $1988 \quad[\mathrm{~N}=529]$ & $0.228(0.421)$ & $0.387(0.489)$ & $0.225(0.419)$ & $0.431(0.499)$ & $0.000(0.000)$ & $0.000(0.000)$ \\
\hline $\begin{array}{l}\text { The spouse has lived in the country of origin before } \\
\text { marriage - } 1988[N=529]\end{array}$ & $0.564(0.498)$ & $0.658(0.477)$ & $0.289(0.455)$ & $0.446(0.501)$ & $0.234(0.427)$ & $0.338(0.476)$ \\
\hline $\begin{array}{l}\text { The immigrants' attitude in } 1988 \text { are negative } \\
\text { concerning the following questions [N=529]: } \\
\text { Their children are allowed to choose their spouse } \\
\text { themselves } \\
\text { Their children are allowed to marriage a Dane }\end{array}$ & $\begin{array}{l}0.069(0.255) \\
0.267(0.445)\end{array}$ & $\begin{array}{l}0.117(0.323) \\
0.369(0.485)\end{array}$ & $\begin{array}{l}0.153(0.362) \\
0.198(0.400)\end{array}$ & $\begin{array}{l}0.262(0.443) \\
0.508(0.504)\end{array}$ & $\begin{array}{l}0.078(0.270) \\
0.063(0.244)\end{array}$ & $\begin{array}{l}0.104(0.307) \\
0.039(0.195)\end{array}$ \\
\hline Discrimination index $^{2)}[\mathrm{N}=517]$ & $2.6(0.42)$ & $2.6(0.54)$ & $2.8(0.40)$ & $2.8(0.36)$ & $2.8(0.44)$ & $2.8(0.87)$ \\
\hline Number of observations & 126 & 133 & 135 & 86 & 103 & 110 \\
\hline
\end{tabular}

1) More than 5 pupils in own school class at basic school were immigrants.

2) We have constructed a discrimination index based on the information from 3 separate questions in the survey regarding the immigrants' experiences from the school days in Denmark: Were you teased in school? Did a teacher treat you worse than the ethnic Danish children? Did you feel uncomfortable in school? They could answer: $1=$ seldom or never, $2=$ now and then or $3=$ frequently. The index is calculated as the mean of the answers to the three questions. 


\section{Appendix B}

Table B.1. Coefficients from estimation of the level of formal education (enrolled or having completed a formal education) - basic model. 1999. Ordered probit specification. (Std. err. in parentheses)

\begin{tabular}{|c|c|c|c|}
\hline & All & Men & Women \\
\hline Age indicators & insignificant & insignificant & insignificant \\
\hline Woman & $\begin{array}{l}-0.016 \\
(0.096)\end{array}$ & - & - \\
\hline Pakistani & $\begin{array}{c}0.552 * * * \\
(0.160)\end{array}$ & $\begin{array}{c}0.596 * * * \\
(0.2101\end{array}$ & $\begin{array}{l}0.603 * * \\
(0.262)\end{array}$ \\
\hline Turkish & $\begin{array}{l}0.140 \\
(0.164)\end{array}$ & $\begin{array}{c}0.096 \\
(0.231)\end{array}$ & $\begin{array}{c}0.254 \\
(0.247)\end{array}$ \\
\hline Mother's education & $\begin{array}{c}0.048^{* * *} \\
(0.013)\end{array}$ & $\begin{array}{c}0.052 * * * \\
(0.019)\end{array}$ & $\begin{array}{l}0.046^{* *} \\
(0.020)\end{array}$ \\
\hline Age at immigration $0-6$ years & $\begin{array}{l}-0.115 \\
(0.123)\end{array}$ & $\begin{array}{c}0.069 \\
(0.178)\end{array}$ & $\begin{array}{l}-0.281 \\
(0.180)\end{array}$ \\
\hline Age at first marriage & $\begin{array}{c}0.053^{* * *} \\
(0.017)\end{array}$ & $\begin{array}{c}0.083^{* * *} \\
(0.024)\end{array}$ & $\begin{array}{c}0.014 \\
(0.027)\end{array}$ \\
\hline Language: Very good & $\begin{array}{c}0.795^{* * *} \\
(0.127)\end{array}$ & $\begin{array}{c}0.640 * * * \\
(0.175)\end{array}$ & $\begin{array}{c}0.959 * * * \\
(0.190)\end{array}$ \\
\hline $\begin{array}{l}\text { Neighbourhood: More than } 5 \text { immigrants in } \\
\text { school class }\end{array}$ & $\begin{array}{l}-0.357 \\
(0.281)\end{array}$ & $\begin{array}{l}-0.162 \\
(0.372)\end{array}$ & $\begin{array}{l}-0.732 \\
(0.460)\end{array}$ \\
\hline Married to a marriage migrant & $\begin{array}{c}-0.345^{* * *} \\
(0.130)\end{array}$ & $\begin{array}{l}-0.245 \\
(0.184)\end{array}$ & $\begin{array}{c}-0.495 * * * \\
(0.186)\end{array}$ \\
\hline Religion: Islam & $\begin{array}{l}-0.186 \\
(0.151)\end{array}$ & $\begin{array}{l}-0.170 \\
(0.206)\end{array}$ & $\begin{array}{l}-0.212 \\
(0.234)\end{array}$ \\
\hline $\begin{array}{l}\text { Attitude: Children should not be allowed to } \\
\text { marry a Dane }\end{array}$ & $\begin{array}{l}-0.177 \\
(0.133)\end{array}$ & $\begin{array}{l}-0.137 \\
(0.202)\end{array}$ & $\begin{array}{l}-0.324^{*} \\
(0.188)\end{array}$ \\
\hline Cut-off $1\left(\mu_{t}\right)$ & $\begin{array}{c}0.462 \\
(0.206)\end{array}$ & $\begin{array}{c}0.588 \\
(0.292)\end{array}$ & $\begin{array}{c}0.329 \\
(0.289)\end{array}$ \\
\hline Cut-off $2\left(\mu_{2}\right)$ & $\begin{array}{c}1.163 \\
(0.208)\end{array}$ & $\begin{array}{c}1.206 \\
(0.296)\end{array}$ & $\begin{array}{c}1.163 \\
(0.292)\end{array}$ \\
\hline Cut-off $3\left(\mu_{3}\right)$ & $\begin{array}{c}1.568 \\
(0.210)\end{array}$ & $\begin{array}{c}1.594 \\
(0.301)\end{array}$ & $\begin{array}{c}1.601 \\
(0.297)\end{array}$ \\
\hline Cut-off $4\left(\mu_{4}\right)$ & $\begin{array}{c}2.149 \\
(0.217)\end{array}$ & $\begin{array}{c}2.178 \\
(0.309)\end{array}$ & $\begin{array}{c}2.191 \\
(0.309)\end{array}$ \\
\hline Log likelihood & -772 & -414 & -347 \\
\hline Pseudo R-square & 0.118 & 0.121 & 0.135 \\
\hline No. of obs. & 640 & 336 & 304 \\
\hline
\end{tabular}

*** significant at a $1 \%$ level, $* *$ significant at a $5 \%$ level, ${ }^{*}$ significant at a $10 \%$ level 
Table B.2. Marginal effects of a unit change in selected explanatory variables from estimation of the level of formal education (enrolled or having completed a formal education) - basic model. 1999. Ordered probit specification. (Std. err. in parentheses).

\begin{tabular}{|c|c|c|c|c|c|}
\hline All: & No education & Vocational & Short theoretic & Medium theoretic & Long theoretic \\
\hline $\begin{array}{l}\text { Indicators for age, gender, } \\
\text { Turks, religion, attitude } \\
\text { concerning marriage, age at } \\
\text { immigration and } \\
\text { neighbourhood variable }\end{array}$ & Insignificant & Insignificant & Insignificant & Insignificant & Insignificant \\
\hline Pakistani & $-0.220(0.064)^{* * *}$ & $0.046(0.015)^{* * *}$ & $0.053(0.016)^{* * *}$ & $0.067(0.021)^{* * *}$ & $0.054(0.017)^{* * *}$ \\
\hline Mother's education & $-0.019(0.005)^{* * *}$ & $0.004(0.001)^{* * *}$ & $0.005(0.001)^{* * *}$ & $0.006(0.002)^{* * *}$ & $0.005(0.001)^{* * *}$ \\
\hline Age at first marriage & $-0.021(0.006)^{* * *}$ & $0.004(0.002)^{* * *}$ & $0.005(0.002)^{* * *}$ & $0.006(0.002)^{* * *}$ & $0.005(0.002)^{* * *}$ \\
\hline Language: Very good & $--0.317(0.051)^{* * *}$ & $0.066(0.016)^{* * *}$ & $0.076(0.015)^{* * *}$ & $0.097(0.018)^{* * *}$ & $0.079(0.015)^{* * *}$ \\
\hline Married to a marriage migrant & $0.137(0.051)^{* * *}$ & $-0.029(0.012)^{* *}$ & $-0.033(0.013)^{* *}$ & $-0.042(0.016)^{* *}$ & $-0.034(0.013)^{* * *}$ \\
\hline \multicolumn{6}{|l|}{ Men } \\
\hline $\begin{array}{l}\text { Indicators for age, Turks, } \\
\text { religion, age at immigration } \\
\text { and neighbourhood variable }\end{array}$ & Insignificant & Insignificant & Insignificant & Insignificant & Insignificant \\
\hline Pakistani & $-0.238(0.084)^{* * *}$ & $0.035(0.026)^{* *}$ & $0.052(0.020)^{* *}$ & $0.078(0.030)^{* * *}$ & $0.073(0.027)^{* * *}$ \\
\hline Mother's education & $-0.021(0.008) * * *$ & $0.003(0.001)^{* *}$ & $0.004(0.002)^{* *}$ & $0.007(0.003)^{* *}$ & $0.006(0.002)^{* *}$ \\
\hline Age at first marriage & $-0.033(0.010)^{* * *}$ & $0.005(0.002)^{* *}$ & $0.007(0.002)^{* * *}$ & $0.011(0.003)^{* * *}$ & $0.010(0.003)$ \\
\hline Language: Very good & $-0.255(0.070)^{* * *}$ & $0.037(0.015)^{* *}$ & $0.055(0.018)^{* * *}$ & $0.084(0.026)^{* * *}$ & $0.078(0.023) * * *$ \\
\hline Married to a marriage migrant & $0.097(0.073)$ & $-0.014(0.011)$ & $-0.021(0.016)$ & $-0.032(0.024)$ & $-0.030(0.023)$ \\
\hline $\begin{array}{l}\text { Attitude: Children should not } \\
\text { be allowed to marry a Dane }\end{array}$ & $0.054(0.080)$ & $-0.008(0.012)$ & $-0.012(0.018)$ & $-0.018(0.027)$ & $-0.017(0.024)$ \\
\hline \multicolumn{6}{|l|}{ Women } \\
\hline $\begin{array}{l}\text { Indicators for age, Turks, } \\
\text { religion, age at immigration } \\
\text { and neighbourhood variable }\end{array}$ & Insignificant & Insignificant & Insignificant & Insignificant & Insignificant \\
\hline Pakistani & $-0.240(0.104)^{* *}$ & $0.075(0.036)^{* *}$ & $0.063(0.029)^{* *}$ & $0.063(0.029)^{* *}$ & $0.040(0.019)^{* *}$ \\
\hline Mother's education & $-0.018(0.008)^{* *}$ & $0.006(0.003)^{* *}$ & $0.005(0.002)^{* *}$ & $0.005(0.002)^{* *}$ & $0.003(0.001)^{* *}$ \\
\hline Age at first marriage & $-0.005(0.11)$ & $0.002(0.003)$ & $0.001(0.003)$ & $0.001(0.003)$ & $0.001(0.002)$ \\
\hline Language: Very good & $-0.383(0.076)^{* * *}$ & $0.119(0.034)^{* * *}$ & $0.100(0.025)^{* * *}$ & $0.100(0.025)^{* * *}$ & $0.064(0.019)^{* * *}$ \\
\hline Married to a marriage migrant & $0.197(0.074)^{* * *}$ & $-0.061(0.026)^{* *}$ & $-0.051(0.021)^{* *}$ & $-0.052(0.021)^{* *}$ & $-0.033(0.014)^{* *}$ \\
\hline $\begin{array}{l}\text { Attitude: Children should not } \\
\text { be allowed to marry a Dane }\end{array}$ & $0.129(0.075)^{*}$ & $0.040(0.024)^{*}$ & $-0.034(0.020)^{*}$ & $-0.034(0.020)^{*}$ & $-0.022(0.013)$ \\
\hline
\end{tabular}

*** significant at a $1 \%$ level, ** significant at a 5\% level, ${ }^{*}$ significant at a $10 \%$ level

1) Calculated at the mean value of the continuous explanatory variables. For the dummy variables, the marginal effect is calculated as the discrete change of the variable from 0 to 1 . 


\section{Appendix C}

In order to instrument the variable age at first marriage, which we expect to be endogenous to the decision concerning educational attainment, we have experimented with a number of variables available in the survey data from 1988 and 1999. Since the variables from the 1988 survey are determined 11 years before the year of observation for the key variable in this study of educational attainment in 1999, we prefer to use a number of variables from the 1988 survey, despite missing information for a number of observations on the 1988 variables. When predicting the age at first marriage, we do not get any predictions for those observations who were not included in the 1988 survey. We add an indicator variable in the EDUC or LEVEL estimation for missing information on predicted age at first marriage.

The weak point of the IV estimator is the estimation of (5). Our experiments show that despite the richness of the data, the instruments are fairly weak, and the determination of (5) is low with pseudo R-square values less than $10 \%$. Weak instruments may imply greater bias than estimates without IV. Further, some of the instruments may not be orthogonal to the educational decision. In order to test the validity of the instruments, we follow the strategy used by Trostel et al. (2002) and Bound et al. (1995). First we test whether the instruments significantly affect the age at first marriage variable, see Table C, column 1, which shows the results from the preferred tobit estimation of age at first marriage.(The preferred estimations are the results of a number of experiments where we have tested the instruments by including the instruments as additional variables in the probit estimation of educational attainment, along the lines suggested by the tests of the instruments). In the second step, we enter each of the instruments in the educational attainment relation, additional to all the other variables in the wage equation in order to test whether the instruments have a significant effect on the wage residuals, see column 2. Since there are large differences between men and women, we also perform this estimation for men and women separately, columns 3-4. If the instrument are valid, $t-$ statistic should indicate insignificance. This holds for most of the IV-variables, while for a few we are not able to avoid some correlation with age at first marriage. If these instruments are dropped as instruments and also included directly in the relation explaining educational attainment, the predicted value of age at first marriage becomes an even more weak (insignificant) variable in the estimation of educational attainment.

In overall, the low explanatory power of the instruments in column 1 and the difficulties with respect to finding instruments which are not directly affecting the educational attainment indicate that we do not have very good instruments in the data set for the purpose of this study. 
Table C. Instrumentation of age at first marriage and test of instruments. ${ }^{\text {I) }}$

\begin{tabular}{|c|c|c|c|c|}
\hline & Tobit & Probit & Probit & Probit \\
\hline Sample & All & All & Men & Women \\
\hline Dependent variable & $\begin{array}{l}\text { Age at first } \\
\text { marriage }\end{array}$ & EDUCII & EDUCII & EDUCII \\
\hline Parents come from rural area in origin country & $-0.305(0.586)$ & $0.104(0.147)$ & $0.404(0.208)^{*}$ & $-0.196(0.229)$ \\
\hline Religion is important & $-1.667(0.613)^{* * *}$ & $0.091(0.155)$ & $0.258(0.258)$ & $-0.221(0.257)$ \\
\hline Parents' attitude: Child should marry early & $1.073(0.779)$ & $-0.159(0.193)$ & $-0.407(0.268)$ & $0.218(0.327)$ \\
\hline $\begin{array}{l}\text { Feel more as a Dane than as a } \\
\text { Turkish/Pakistani/Ex-Yugoslavian person, } 1988\end{array}$ & $-1.181(0.664)^{*}$ & $0.065(0.163)$ & $-0.082(0.216)$ & $0.215(0.297)$ \\
\hline $\begin{array}{l}\text { Many friends who are non-immigrants (Danes), } \\
1988\end{array}$ & $0.945(0.637)$ & $0.114(0.157)$ & $-0.173(0.239)$ & $0.317(0.243)$ \\
\hline $\begin{array}{l}\text { Parents' attitude positive with respect to children's } \\
\text { potential return migration, } 1988\end{array}$ & $1.056(0.901)$ & $0.022(0.222)$ & $0.249(0.267)$ & $-0.831(0.476)^{*}$ \\
\hline Ethnic concentration & $-1.279(5.887)$ & $1.061(1.467)$ & $1.558(0.203)$ & $-1.552(0.2 .458)$ \\
\hline Married to a person from own family. 1988 & $-0.349(0.758)$ & $0.396(0.201)^{* *}$ & $0.359(0.300)$ & $0.547(0.297)^{*}$ \\
\hline Marriage was arranged, 1988 & $0.216(0.788)$ & $-0.028(0.205)$ & $0.234(0.324)$ & $-0.251(0.298)$ \\
\hline $\begin{array}{l}\text { Attitude concerning own (future) children: They } \\
\text { should be allowed to choose their own spouse }\end{array}$ & $0.500(0.803)$ & $0.324(0.206)$ & $0.345(0.327)$ & $0.246(0.297)$ \\
\hline Age $28-30$ & $-2.698(0.850)^{* * *}$ & $-0.178(0.217)$ & $0.317(0.303)$ & $-0.019(0.344)$ \\
\hline Age 31-33 & $-0.044(0.691)$ & $-0.072(0.179)$ & $0.159(0.239)$ & $-0.408(297)$ \\
\hline Woman & $-0.227(0.563)$ & $0.246(0.142)^{*}$ & - & - \\
\hline Pakistani & $2.949(1.006)^{* * *}$ & $0.546(0.245)^{* *}$ & $0.536(0.312)^{*}$ & $0.926(0.481)$ \\
\hline Turkish & $1.739(0.976)^{*}$ & $0.276(0.244)$ & $0.196(0.339)$ & $0.589(0.415)$ \\
\hline Mother's education & $0.144(0.083)^{*}$ & $0.071(0.021)^{* * *}$ & $0.099(0.032)^{* * *}$ & $0.076(0.033)^{* *}$ \\
\hline Age at immigration $0-6$ years & $0.550(0.709)$ & $-0.016(0.179)$ & $0.151(0.253)$ & $-0.310(0.280)$ \\
\hline Language: Very good & $2.171(0.646)^{* * *}$ & $0.782(0.164)^{* * *}$ & $0.528(0.230)$ & $1.181(0.262)^{* * *}$ \\
\hline $\begin{array}{l}\text { Neighbourhood: More than } 5 \text { immigrants in school } \\
\text { class }\end{array}$ & $-0.207(1.207)$ & $-0.531(0.327)$ & $-0.047(0.453)$ & $-1.222(0.582)^{* *}$ \\
\hline Married to a marriage migrant & $-4.486(0.674)^{* * *}$ & $-0.546(0.172)^{* * *}$ & $-0.642(0.244)^{* * *}$ & $-0.703(0.272)^{* * *}$ \\
\hline Religion: Islam & $-3.730(0.935) * *$ & $-0.551(0.225)^{* *}$ & $-0.802(0.305)^{* * *}$ & $-0.468(0.387)$ \\
\hline $\begin{array}{l}\text { Attitude: Children should not be allowed to marry } \\
\text { a Dane }\end{array}$ & $-1.159(0.644)^{*}$ & $-0.327(0.166)^{* *}$ & $-0.305(0.255)$ & $-0.448(0.250)^{*}$ \\
\hline Constant term & $27.251(1.48)^{* * *}$ & $-0.713(0.360)^{* *}$ & $-0.689(0.504)$ & $-0.190(0.561)$ \\
\hline Log likelihood & -1240 & -254 & -135 & -101 \\
\hline Pseudo R-square & 0.078 & 0.216 & 0.222 & 0.318 \\
\hline Number of observations & 479 & 467 & 251 & 216 \\
\hline
\end{tabular}

*** significant at a $1 \%$ level, $* *$ significant at a $5 \%$ level, $*$ significant at a $10 \%$ level

1) The tobit-estimation of age at first marriage is based only on individuals observed both in 1988 and 1999. The test, i.e. estimation of the EDUCII model including the instrument variables, is also based only on these observations. 


\section{IZA Discussion Papers}

\begin{tabular}{|c|c|c|c|c|}
\hline No. & Author(s) & Title & Area & Date \\
\hline 734 & S. Wolter & Sibling Rivalry: A Six Country Comparison & 2 & 03/03 \\
\hline 735 & $\begin{array}{l}\text { R. Desmet } \\
\text { A. Jousten } \\
\text { S. Perelman } \\
\text { P. Pestieau }\end{array}$ & $\begin{array}{l}\text { Micro-Simulation of Social Security Reforms in } \\
\text { Belgium }\end{array}$ & 3 & $03 / 03$ \\
\hline 736 & $\begin{array}{l}\text { I. Bolvig } \\
\text { P. Jensen } \\
\text { M. Rosholm }\end{array}$ & The Employment Effects of Active Social Policy & 6 & 03/03 \\
\hline 737 & $\begin{array}{l}\text { A. L. Booth } \\
\text { M. Francesconi } \\
\text { G. Zoega }\end{array}$ & $\begin{array}{l}\text { Unions, Work-Related Training, and Wages: } \\
\text { Evidence for British Men }\end{array}$ & 3 & $03 / 03$ \\
\hline 738 & V. Grossmann & $\begin{array}{l}\text { Managerial Job Assignment and Imperfect } \\
\text { Competition in Asymmetric Equilibrium }\end{array}$ & 1 & $03 / 03$ \\
\hline 739 & M. Fertig & $\begin{array}{l}\text { Who's to Blame? The Determinants of German } \\
\text { Students' Achievement in the PISA } 2000 \text { Study }\end{array}$ & 1 & 03/03 \\
\hline 740 & $\begin{array}{l}\text { B. T. Hirsch } \\
\text { S. L. Mehay }\end{array}$ & $\begin{array}{l}\text { Evaluating the Labor Market Performance of } \\
\text { Veterans Using a Matched Comparison Group } \\
\text { Design }\end{array}$ & 6 & 03/03 \\
\hline 741 & $\begin{array}{l}\text { B. T. Hirsch } \\
\text { D. A. Macpherson }\end{array}$ & $\begin{array}{l}\text { Wages, Sorting on Skill, and the Racial } \\
\text { Composition of Jobs }\end{array}$ & 5 & 03/03 \\
\hline 742 & R. A. Easterlin & Building a Better Theory of Well-Being & 3 & 03/03 \\
\hline 743 & $\begin{array}{l}\text { G. Heineck } \\
\text { J. Schwarze }\end{array}$ & $\begin{array}{l}\text { Substance Use and Earnings: The Case of } \\
\text { Smokers in Germany }\end{array}$ & 5 & 03/03 \\
\hline 744 & $\begin{array}{l}\text { M. R. West } \\
\text { L. Woessmann }\end{array}$ & $\begin{array}{l}\text { Which School Systems Sort Weaker Students } \\
\text { into Smaller Classes? International Evidence }\end{array}$ & 2 & 03/03 \\
\hline 745 & L. Woessmann & $\begin{array}{l}\text { Educational Production in East Asia: The Impact } \\
\text { of Family Background and Schooling Policies on } \\
\text { Student Performance }\end{array}$ & 2 & 03/03 \\
\hline 746 & $\begin{array}{l}\text { A. Ammermueller } \\
\text { H. Heijke } \\
\text { L. Woessmann }\end{array}$ & $\begin{array}{l}\text { Schooling Quality in Eastern Europe: } \\
\text { Educational Production During Transition }\end{array}$ & 4 & $03 / 03$ \\
\hline 747 & J. Messina & Sectoral Structure and Entry Regulations & 3 & $03 / 03$ \\
\hline 748 & M. Pflüger & $\begin{array}{l}\text { Economic Integration, Wage Policies and Social } \\
\text { Policies }\end{array}$ & 2 & $04 / 03$ \\
\hline 749 & $\begin{array}{l}\text { V. Jakobsen } \\
\text { N. Smith }\end{array}$ & $\begin{array}{l}\text { The Educational Attainment of the Children of } \\
\text { the Danish 'Guest Worker' Immigrants }\end{array}$ & 1 & $04 / 03$ \\
\hline
\end{tabular}

An updated list of IZA Discussion Papers is available on the center's homepage www.iza.org. 